\title{
Immunological and Immunohistological Studies on Human Chorionic Gonadotropin (by Fluoresent Antibody Technique)
}

\author{
Kanji KASAI \\ Department of Obstetrics and Gynecology, Faculty of Medicine, Kyoto University, \\ Kyoto, Japan (Director : Professor Toshio Nishimura, M.D.)
}

The studies were started by the immunization of albino-rabbits with antigen HCG which was extracted from the urine of normal human pregnancies in the first trimester and highly purified to 5012 or 5427 I.U. per mg. of biological activity.

The antigen protein was separated by the alum precipitate method using $10.0 \%$ alum solution. The anti-HCG rabbit antiserum gave only one band in gel diffusion and showed a precipitate in gamma globulin fraction by immunoelectrophoretic analysis.

Crude globulins of the antiserum were extracted by the half-saturated method with saturated ammonium sulfate solution. Crude globulins were conjugated with fluorescein isothiocyanate. Specific anti-HCG fraction was obtained by DEAE cellulose column chromatography with elute of $0.05 \mathrm{M}$. phosphate buffer solution at $\mathrm{pH}=6.40$. Materials were collected from normal chorionic tissues throughout all the gestational periods, hydatidiform mole in the first trimester and the tumors of chorionepithelioma. They were fixed in $95.0 \%$ cold ethanol and embedded in paraffin blocks according to Sainte-Marie's procedure. These paraffin blocks were sectioned into 3 microns' thick slices and exposed to fluorescent microscopy after adequate staining. Control conjugates against anti-HCG conjugate were prepared to certify the specific staining of anti-HCG conjugate.

In the first trimester, chorionic tissues presented linear localization in syncytiotrophoblasts only, which seemingly paralleled the basal membrane. The HCG also localized in the apex area of the villi, which seemed to increase the amount of accumulation in accordance with their arrangement towards the brush border. These findings suggested that HCG in cytoplasm would flow out into the intervillous space through the brush border. The accumulation of HCG in cytoplasm was divided into two different types: one was finely granular and the other a diffuse type. Both of them were characteristic to normal chorionic tissues.

In the second trimester, HCG localized also in syncytiotrophoblasts, especially in the syncytial knots, accumulating in a diffuse way.

In the third trimester, HCG was not distinctly recognized in cytoplasm except at the site of border membranes.

Hydatidiform mole presented bright fluorescence in syncytiotrophoblasts only. No fluorescence was recognized at any site of tissue when the sections were stained with any of the other control conjugates. There were also two different types of intracellular accu- 
mulations of HCG: one was a finely granular type and the other was a netted type. The characteristic finding in hydatidiform mole was coexistence of the two different types of accumulation in random arranged syncytiotrophoblasts.

Specific anti-HCG conjugate presented also birght fluorescence in syncytiotrophoblasts of the sections of chorionepithelioma. It was clarified that chorionic tumor cells could synthesize HCG but the intracytoplasmic accumulation of HCG characteristically consisted on only netted type. This was quite a different finding comparing with the accumulation in normal villi, so that the HCG of the tumor HCG seemed to have a different kind of character from that of normal pregnancy. Of secretion mechanism in the case of chorionepithelioma, it was not clear with what process tumor HCG would flow out form the cells.

In the experiments with frozen sections the findings were the same as that with paraffin sections throughout all the cases in the study. Of the control conjugates, no fluorescence was recognized in the sections except where staining with specific anit-HCG conjugate which was absorbed by normal human sera or by urine components was done and the findings of the two were identical

From the fact that HCG localized only in syncytiotrophoblasts in all cases in these studies, it is suggested that HCG, or at least immunologically specific reactive substance to anti-HCG might be produced in syncytiotrophoblasts only.

The characteristic discrepancy between HCG of normal pregnancy and the tumor HCG was diagnosed by the gel diffusion technique.

(pp. 907 936) 


\section{人䋐毛性々腺刺戟ホルモン（HCG）の免疫学的, 免疫組織学的研 究}

（蛍光抗体法による）

京都大学医学部婦人科学産科学教室 (指導 西村敏雄教授)

笠井寛司

(昭和43年 3 月 6 日受付)

免疫学的娃娠早期診断を可能ならしめた HCG の免疫学的研究は, 䋘毛性腫愓患者の予後判定等に 拡大されようとしている。妊娠性 HCG と腫愓性 HGG の間に差異はないか。前者を抗原として得た 抗 HCG 抗体に螢光を附加し，䄉毛性組織を検討した結果，雨者間には細胞内分布状態に明らかな差 を認め, gel-diffusion 法でも差を認めた。 HCG は絨毛組織中の syncytiotrophoblasts から分泌され る.

序論

人絨毛性々腺刺㦸ホルモン $(\mathrm{HCG})$ そは既に多方面から研究の手が差しのべられ，幾多の報告をみてい るとてろであるが，その本質的な解明にはまだ程遠い現状にある。しかし HCG を更に一歩進めて免疫学 的, 免疫組織学的な立場から検索すれば，少なくともそれが将来の免疫化学的理論て重要なる足掛りを提供 するであろうととは否定さるべくもない，即ち表題として掲げたての研究方法はとりもなおさず HCG の 免疫学的, 免度化学的な研究のみならず更には蛋白化学を通して HCG 周辺の問題解明に役立つ発展性を 有する有効なる一助であろうという意である.

\section{第 1 節 HCG の由来}

既に人脳下垂体から性腺活動に関与するホルモンが分泌されることは古くから知られている。垂体ホル モンについては, 貯蔵されているホルモン量が比較的多いととが組織学的, 電子顕微鏡て察知されているが, 一方下垂体性々腺刺㦸ホルモンとは別に人胎船組織から，同様に性腺へ影響を示寸物質が分泌されるらしい ことが1920年 Hirose ${ }^{1)}$ により初めて報告された。即ち人胎盤 homogenate を抽出し，家鬼にそれを投与す るととによつて家鬼卵巣汇黄体を発生せしめるととが知られた。1927年 Zondek \& Aschheim ${ }^{2)}$ が妊婦尿を

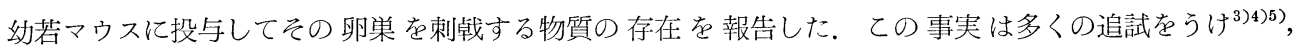
Evans $^{6}$ ) らよつて報告された下垂体性々腺刺㦸ホルモン (human pituitary gonadotropin, HPG) と区別 され，乙れが䄉毛由来であることが明らかになつた，従来 HCG については生物学的活性面を主体とした 研究がなされてきた感があり幾多の業績も報告されているが，HCG は卵巣に対して必ずしも一定の反応系 をもつとはいえず，ての点から HCG がもつ生物活性面の分離を行なう試みが多数の研究者によつてなされ ている。 まず Fevold ${ }^{7)}$ らがその可能性に光明を投じ，生物学的作用に基づいて FSH 作用と LH 作用に区 分命名した。一方 HPG には FSH ならびに LH 作用の他に Evans ${ }^{8)}$ らによつて認められた LTH 作用 も含まれているが，てうした HPG 及び HGG 亿共通に認められる FSH 及び LH 作用についても，個 々に特異的に検出し得る生物学的活性検定法がなく, 従来から幾多の方法が考案実施されてはいるものの尚

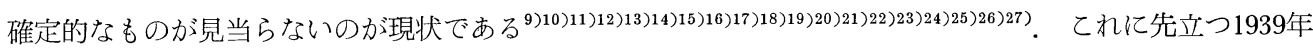
Health Organization of the League of Nations の協定に基づき HGG の国際単位の取決めがなされた が，乙れはあくまで生物学的活性面から定められており HCG がもつ生物学的成分については考慮が払わ 
れていない. しかも HGG はとの標準品との量的反応曲線をもつて活性が決められるため, 甚だ不合理で あるといえる。乙れを打開しょうとして, 生物学的作用を示しつつ HCG のもつ蛋白化学分析を試みよう とする動きが出てきた. Proteohormone の一つである ACTH, ADH (antidiuretic hormone) 及び insulin などは既にその化学構造式まで決定されたが，FSH. LH 更には LTH なぞ Gonadotropin に関しては化 学構造はおろか蛋白化学的分析は甚で遅々としたものである。しかし現在 FSH，LH などの標準品として $\mathrm{NIH}$ 製品が用いられることが多く, 生物学的作用面だけをとりあげるならば可成の高効力をもつ FSH, LH の精製品が出現しているが，尚純品とはいい難い状態である。乙れは Gonadotropin のもつ蛋白の speciesspecificity の問題も多分に関与するし，単に生物学的活性面の強調によることにも大きな要因があるといえ る。したがつて究極にはこれらがもつ蛋白即ち polypeptide 系の解明を待た敞ばならないととにならう。

\section{第 2 節 HCG の局在論}

HCG の性格分析の詳細は省略し，本論文の重要な閭題点でもあるHCG の分泌部位ならびに局在に関す る現在までの諸報告にみる変遷の概略は次のようである。HGG が絨毛組織から分泌される点は明らかにな つたが，絨毛組織成分のうち，どれが HCG の産生，分泌值接関与するかについては今尚論議の絶えぬ ところである。既に人絨毛組織が内分泌機能をるつととは1902年 Hulban が示唆しているが，その後ての問 題はやや等閑に附されたようであり，上述のZ Zondek \& Aschheim らによつて再認識され，その後迂余曲折 の経過をたどり, Bickenbach ${ }^{28)}$ 亿つて初めて人絨毛組織のホルモン产生作用のより具体的な問題が提起さ れた。乙れまで，人絨毛組織成分のうち HCG 亿関与するのは syncytiotrophoblast（ $\mathrm{S}$ 細胞と略記）より も cytotrophoblast ( G 細胞と略記) 飞重点が置かれていた。 その根拠としては，1）娃娠経過中の血中， 尿中の gonadotropic activityはC細胞の增殖ならびに退行に平行した推移を示すてと(1943年, Wislocki $\left.{ }^{29}\right)$, 2）縅毛組織の培養では $\mathrm{S}$ 細胞の outgrowth が不良であるに反して $\mathrm{C}$ 細胞の增殖は良好であり，乙れに伴 つて培養 medium 中の gonadotropic activity が增加する事実，3）更とは HCG 合成と関係ある mucoprotein が組織学的にC 細胞内に認められる点 $\left(\right.$ Pearse $\left.{ }^{30)}\right)$. 4) 細胞活性を示す acid phosphatase 活性 と $\mathrm{G}$ 細胞の消長が平行する事 5) alkaline phosphatase 活性や RNA が $\mathrm{S}$ 細胞に多く認められるなどの点 から G 細胞説が有力であつた。しかし一方では 6 ）組織中，血中及び尿中の gonadotropic activity は trophoblast 内の小胞体の発達程度と平行し，7）組織培莒でば組織細胞の同定が不可能に近いという事実, 8) mucoprotein は $\mathrm{G}$ 細胞に限るととなく， $\mathrm{S}$ 細胞にも認められており $\left(\right.$ Palik $^{31}$ ， Zilliacus $\left.{ }^{34)}\right)$, 亦電顕所見 ${ }^{33)}$ ${ }^{34)}$ ，更には電頙と組織化学所胃 ${ }^{35}$ から $\mathrm{S}$ 細胞説の抬頭をみるようになつた。乙れらの諸報告の如く，各々異 つた立場から HCG の産生部位，局在に多大の努力が払われているにも拘らず，尚確認の得られないのが 実情である。既に ACTH 等では HCG とは比較になら研究の進展をみるにも拘らず，一圆複雑な題題 が提起されている実情からしても，例觉ば HCG の前駆物質という概念を導入する最近の動きをみると， 結局 HCG のもつ蛋白解明問題が州着过ざる得ないであろう。

\section{第 3 節 HGG の抗原性}

Collip \& Anderson ${ }^{36)}$ らは動物に長期にわたり HCG を投与した場合, HCG のもつ生物学的作用が消失 または減少するととを見出した。てれを HGG の生物学的活性に対する中和（neutralization）と見做し， HCG の長期投与によつて被投与動物体内にある種の物筫の産生がみられると考え，乙れを antigonadotropin と名付けた.

こうした異種蛋白を動物に投与することによつて中和物質の産生を促す事実は Hamburger によつても確 認された. 即ち HCG のもつ抗原性 (antigenicity) はHCG のもつ分子構造中の蛋白部分によつて発現 されるものであろうととが明らかになつた．然らば HCG の抗原性とは何であるかを考学る時, 当然 HCG と HPG の関係を論じなければならない，前述の通り HCG と HPG には生物学的活性が共通していると いつてよい FSH 及び LH 雨成分がある. また HPG と HMG (human postmenopausal gonadotropin) の間, HMG と HCG の間にもほぼ同様な生物学的作用の共通面がある。従つて HCG とてれら gonadotropins の間の生物学的共通作用のみならず，免疫学的 cross-linkage の問題を考慮しなければならない. 
Goss $^{37)}$ は LH と HCG そついて, Ely ${ }^{38)}$ は FSH と HCG について, Wilde ${ }^{39)}$ は HMG と HCG の間 に, また Paul ${ }^{40)}$ は $\mathrm{HCG}$ と $\mathrm{HPG}$ の間の各々の cross-linkage を報告し, 少なからず単なる contamination 以上の問題（又は要因）が含まれていると述べている。総合すると HCG は生物学的な面と共に免 疫学的又は蛋白化学的な見地からも追究されねばならないが，共通の蛋白部分が決定的な意味をもつか否か という点になると判然としないのである。実際に単に温熱処理を施すだけで生物学的活性と免疫学的活性に は discrepancy がみられることは睍に報告したところである ${ }^{41)}$. 一方例えば HCG に含まれる LH 活性 を主として考えるならば，羊の精製 NIH-LH は分子量約 $23 \times 10^{3}$ ，構成ア之ノ酸は Asp. 10, Thr. 14, Ser. 13, Glu. 3 14, Pro. 25, Gly. 11, Ala. 15 16, Gys. 8〜10, Val. 12 13, Met. 7, Ileu.6, Leu. 12, Tyr. 6, Phe. 5, Lys. 10 11, His. 5, Arg. 8, - $\mathrm{CONH}_{2}$ 12基をもち glucosamin 10, galactosamin 3 をもつ glycoprotein であるてとがわかつている ${ }^{42)}$. てれを用いて免疫学的特異性を検討した報告によれば ${ }^{43)}$, HCG, HMG，人 LH PMSG などとは免度学的 cross-reactivity のない事実がつきとめられている。乙の 点からみると単に生物学的共通作用があるからといつて, 免度学的共通抗原性を包含するてとにはならず, 更に HCG の抗体が，従来の報告にみる如く生物活性面では共通の作用をもつ non-hormone LH 又は同 FSH 製品との間に cross-link-age があるといつても, 単なる夾雑反応の異型的なものであるかも知れない という危惧をもとり去り得ない. 以上のととから考えて, HCG の抗原性を単一 factor と考えるととは不 可能であるが，さりとて LH 活性又は FSH 活性を来す components が単離可能かどうかもわからない現 状においては，HCG を抗原として用いる場合には，乙れの抗原性規定を可及的に最少限度にする，即ち疾 患名，時期等更には抽出方法，純化方法などにつき可及的に明確にする必要があろう.

\section{第 4. 節 螢光抗体法亡 HCG 抗体の実用性}

1960年 Wide \& Gemzell ${ }^{45)}$, Brody \& Carlström ${ }^{46)}$, McKean $^{47)}$ らによつて, 従来 Friedman 反応 ${ }^{48)}$ とか, Mainini 反応 ${ }^{49}$ によつて代表されていた尿中 HCG の生物学的検定法が，免疫学的な方法を用いて検定可能 なととが報告されて以来, 急速に HCG の免疫学的研究ならびに実地臨床面における応用研究が進められ て今日に至つているが，上述の如く HGG の抗原性にも亦それを用いて得られる抗 HGG 抗体にも種々の 未解決な点が多く，基礎的研究は㹝論，実地踟床面でも尚多くの discrepancy が見られるととは揫知のと ころである。主として現在は妊娠の比較的早期診断に用いられる程度であり，HCG 様物質の分泌が認めら

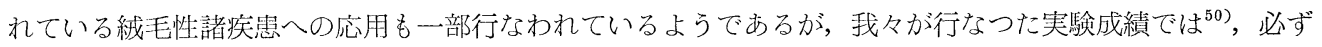
しも臨床的応用に非難のないものでなく, 正常妊娠例に用いても, 定量的にはまだ問題か残されているとい える.

一方特異抗原抗体反応下において, 組織細胞内で展開される生物現象の真の资を捕えようという試みで免 疫組織学の立場から螢光抗体法が考察された。既に抗体蛋白に色素を標識する試みは1930年 Reiner ${ }^{51)}$ によ

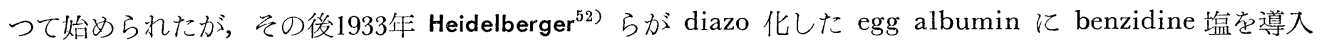
するととに成功し，免度化学面における spectrophotometric な量的研究の端緒を開くことになつた。

これらの業績を基盤として, 螢光抗体法への道を開いたのが Hopkins ${ }^{5354)}$ ら及び Marrack ${ }^{55)}$ である。一方 1941年 Coons ${ }^{56)}$ らは蛋白と色素との結合に成功し，組織内抗原の局在性の追究に成功した ${ }^{57}$. 乙れは極め て画企的な報告であり，乙れを機会として免疫学的見地に立つ組織学として広い分野で応用され，単に基礎 的事実の追究のみならず，臨床上にも迅速診断などに用いて谌だ有効な手段として益々発展の道を歩む結果 となつたのである。因みに1951年 Marshall ${ }^{58)}$ らは初めて螢光抗体法を hormone 物質の研究に応用したの であるが，1958年になつて Cruickshank \& Currie ${ }^{59)}$ が human \& bovine pituitary ACTH, GH 等につい てその体内分布を報告している，一方 HGG に関する螢光抗体法による研究報告は 1962年の Midgley \&

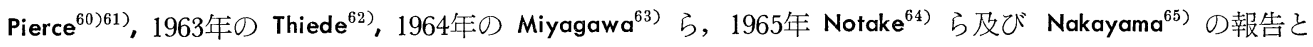

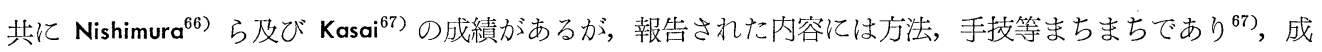

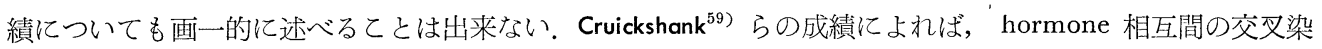
色性を十分に検討したところ，in vitro の交叉反応性がなくても，染色性で明らかな交叉性を認めている。 
彼等の結論によれば hormone 物質の特異染色を得るためには相当慎重でなければならないというととであ り，因みに HCG を例にとつてみても，てれが属する glycoprotein の category 中には, Schultze ${ }^{68)} ら に$ よれば $\alpha_{1}$-acid glycoprotein 又は orosomucoid, $\alpha_{1}$ X-glycoprotein, $\alpha_{1}$-glycoprotein, $\alpha_{2}$-glycoprotein 等が あるなかで現今までの報告には, HCG とてれら glycoproteins の詳細を伝光るものはなく, 亦免度化学上 の諸方法をもつてすれば，蛋白ならびに carbohydrates の純度の定量的測定，又はその detection 亿従来 の hormonal substances 亿対する純度とは異なつた criteria を必要とするととは否定出来ないようである 69770)。乙れらの点を考慮しながらまず抗原 HCG の組織内（正常絨毛組織, 胞状奇胎組織, 絨毛上皮腫々 瘍組織）分布と共に各組織内 HCG の組織，細胞外排出経過ならびにその機序について検討した。

\section{第 I 章＼cjkstart実験材料ならびに実験方法}

\section{第 1 節 実験材料}

\section{(I) 抗 原}

正常妊娠初期妊婦尿中から抽出した HCG を精製乾燥し, その生物学的活性值を 5012I.U./mg. 及び 5427I.U./mg. の二種に純化した製品を帝国藏器株式会社から提供をうけたので，ての二種の HCG を個別 に抗原として用いた．HCG は妊婦尿中に検出されるのみならず，種々の trophoblast 性疾患で，それらの 患者尿中などで検出されており，本実験では HCG 又は HCG 様物質の検索の目的からすれば，それら疾 患にみられる HGG（又は HGG 様物質）を各々抗原として用いるべきことは論をまたない．

一方 HGG の生物学的活性は甚だ不安定であり, 特に純度が高まるにつれて不安定さは増すといわれて いる. 更に生物学的活性と雖も HCG の態度そのものとは，必ずしも平行関係にあるとは言い難く，免疫 学的検索に生物学的単位を直ちに導入するてとは, 今後詳紐な研究を待た称ばならない点であり ${ }^{4777172773),}$ 現段階では差し控えねばならない，したがつてての実験には，基準になるべきものとして一応上記二種の HCG が含有する蛋白量を選んだ.

\section{（II） 被免疫動物}

被免疫動物として，成熟雄白色家鬼（male mature albino-rabbit）を選んだ。抗原の投与量，将来採取 すべき抗血清量等を考慮して体重3.5〜 $4 \mathrm{~kg}$ ののを用いた。

\section{(III) 検索資料}

次に列記するものを検索資料とした。

1. 人正常妊娠初期縅毛組織

2. 人正常奼娠中期䄉毛組織

3. 人正常娃娠末期絨毛組織

4. 胞状奇胎䋐毛組織

5. 䋐毛上皮腫々湯組織

\section{(IV) 螢光色素}

螢光色素としては，1) isothiocyanates 系及び isocyanates 系，2) acid chlorides ${ }^{74}$ 系，3) Diazo 系, 4) その他 triazine chlorides, flavine ${ }^{75}$ 等があるが，抗体蛋白との結合が可能なだけでは使用に適しない し, 螢光強度の程度及び 螢光色素としての安定性などが要求されるため, 実際に用いたのは 1) 系中の Riggs $^{76)}$ によて開発された fluorescein isothiocyanate (FITG) と, tetramethylrhodamine isothiocyanate (TRITC) の二種類で，後者は Hiramoto ${ }^{77)}$ らによつて開発されたものである. 製品は共に Baltimore Biological Laboratory, Inc. U.S.A. のものを用いた. FITC は螢光強度も保たれ, 色素も安定し, 操作も簡単 であり，螢光抗体液の長期保存も可能であるという利点をもつ緑色螢光物質である．後者は橙赤色の螢光物 質であるが，他にある同色系物質に比べて FITC と吸友スペクトルの最大波長が同じである点で利用しや すいと考えた．色素の発光性が，吸収された励起光の吸収部分における強度の高いもの程推賞されるわけで， 螢光波長と吸収光の波長の関係は Stoke の法則により確立している。 螢光の主吸収 peak は $490 \mathrm{~m} \mu$ そその 


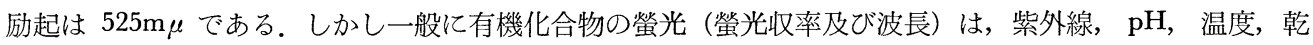
燥度, 溶媒等の要因によつて, 甚だしく影響を受けるから, 各々の要因に対して最も適当と考えられる条件

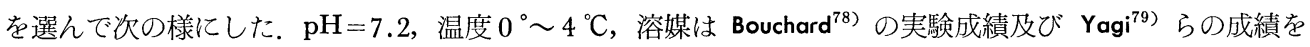
みてもわかることであるが ${ }^{80)}$ ，主として phosphate buffer solution（以下 PBS と略記する）が用いられ るととが多く，ての実験でも PBS を用いた．尚この実験中に用いた諸種 PBS 及び䋧衝液の処方は Table 1 にまとめて記載した.

Table 1 Buffer solution

\begin{tabular}{|c|c|}
\hline \multicolumn{2}{|l|}{ Staining B. $\mathrm{pH}-7.20$} \\
\hline $\mathrm{NaH}_{2} \mathrm{PO}_{4} \cdot 2 \mathrm{H}_{2} \mathrm{O}$ & 22.50 \\
\hline $\mathrm{Na}_{2} \mathrm{HPO}_{4} \cdot 12 \mathrm{H}_{2} \mathrm{O}$ & 126.65 \\
\hline $\mathrm{NaCl}$ & 400.0 \\
\hline Aq. dest. & 50.0 lit. \\
\hline \multicolumn{2}{|l|}{ Starting B. $\mathrm{pH}=8.400 .005 \mathrm{M}$. } \\
\hline $\mathrm{NaH}_{2} \mathrm{PO}_{4} \cdot \mathrm{H}_{2} \mathrm{O}$ & 0.276 \\
\hline $\mathrm{Na}_{2} \mathrm{HPO}_{4} \cdot 7 \mathrm{H}_{2} \mathrm{O}$ & 12.868 \\
\hline Aq. dest. & $10 \cdot 0$ lit. \\
\hline \multicolumn{2}{|l|}{ Carbonate B. $\mathrm{pH}=9.10$} \\
\hline \multicolumn{2}{|c|}{$\begin{array}{l}\text { 1. } \mathrm{Na}_{2} \mathrm{CO}_{3} 5.30 \text { in Aq. } 100 \mathrm{ml} \text {. } \\
\text { 2. } \mathrm{NaHCO}_{3} 4.20 \text { in Aq. } 100 \mathrm{ml} \text {. } \\
\text { 1. and } 2 . \text { mixed }\end{array}$} \\
\hline
\end{tabular}

\section{第 2 節 抗 HCG 家鬼抗血清産生過程}

抗原 HCG の蛋白量を窒素微量測定法 (nitrogen microdetermination technique) ${ }^{81) 82(83) 84) 85(86)}$ によ つて測定したとてろ, 純度 5012I.U./mg のものは $0.602 \mathrm{mg} / \mathrm{mg}$ HCG となり, 純度 5427I.U./mg の ものは $0.645 \mathrm{mg} / \mathrm{mg}$ HGG であつた. HCG 重量 とその含有する蛋白量とは各製品で，ほぼ直線関係 を示すととがわかつた， 因みに純度約 3000I.U./mg 及び1アンプル中 1000I.U. の HCG 製剤では, HCG 重量と含有蛋白量との間には相関々係がみられなかつた。したがつて免度学的検討を行なうためには, 抗原 HCG の純度は少なくとも $5.0 \times 10^{3} \mathrm{I}$.U./mg を要すると考えられる。これらの抗原 HGG 用いて次に述べ る二通りの免度方法を行なつた.

\section{(1) Freund's adjuvant ${ }^{87)}$ を用いる方法}

Freund's adjuvant には incomplete 及び complete の二種類があるが，特異抗体成分の単純化が問題に なるととを考えると, 特に HGG の如く生物学的活性成分の混在をあらかじめ認知しながらその特異抗体 を得ようとする場合には，乙の adjuvant 中に抗酸性菌の死菌（主として結核死菌）を加えないものを用い るべきであろうと考元, incomplete の方を選んだ. まず, 5427I.U./mg の HCG 10.0mg, 蛋白量として $6.45 \mathrm{mg}$ ，を家鬼一匹当りの単位とし，乙れに $1.0 \mathrm{ml}$ の生食水を加えて完全に溶解し，ての上に $0.4 \mathrm{ml}$, Bayol F (Staneco Distribution, U.S.A. 製) 及び表面活性剤として Arlacel A (Atlas Powder, Co. U.S.A. 製） $0.1 \mathrm{ml}$ を加え，約 1 時間，water in oil の状態になるように十分攪拌し，家兔足蹠皮下に 5 ケ所に分割 注射を行なつた．乙れを初回免疫とし，投与した HCG 総量の生物学的単位は $5.4 \times 10^{4}$ I.U. となるが，乙 の数值に信用は置けない. その理由は既述したところである.

(2) Alum precipitate method

原法は1943年 Proom ${ }^{88)}$ が発表した論文にみられる通りであるが，今回ての実験で HCG 抗原に用いた方 
法は，原法を変形し， hormone 抗原特に蛋白性ホルモン抗原に用いて有用ならしめた。乙の方法を HCG

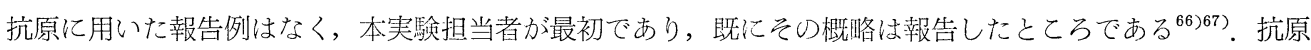
HCG 5012 I.U./mg のものと, 同 5427I.U./mg のものを用いた。投与量はそれぞれの $15.0 \mathrm{mg}$ (蛋白量と して9.25mg及び9.67mg）であり，てれを一匹当りの初回兔度量とした．5427I.U./mg のものは抗原資料の 関係から家鬼一匹分にとどめ, 50121.U./mg のものは家鬼二匹分用意した．向後の方法は両抗原 HCG に 共通のものであるのでまとめて記述する，抗原 $\mathrm{HCG} の 15.0 \mathrm{mg}$ 老生食水 $0.25 \mathrm{ml}$ 亿全量を完全に溶解した あと, 蒸留水 $0.85 \mathrm{ml}$ 加え, 総溶媒量を $1.10 \mathrm{ml}$, とした。 乙れに $10.0 \%$ カリ明鐢液 $\left(\mathrm{AlK}\left(\mathrm{SO}_{4}\right)_{2} \cdot 12 \mathrm{H}_{2} \mathrm{O}\right)$ $0.90 \mathrm{ml}$ を加え，泡立ちを防ぎつつ十分攪找したあと， $5.0 \mathrm{~N} の ~ \mathrm{NaOH}$ で $\mathrm{pH}=6.50$ 亿調整し，白色雲絮 状沈澱を得た。操作はこの間 ice-bath による低温を厳守した。乙の沈澱浮遊液を $4{ }^{\circ} \mathrm{C}, 4000 \mathrm{r}$. . .m. で15分 間遠沈し, 上清を静かに捨てたあと, 生食水で沈渣を十分に洗涤した。洗滌操作には, 生食水 $5.0 \mathrm{ml}$ を用い, $1 / 10000$ 稀勫の merthiolate を一滴加光，15分間， $4{ }^{\circ} \mathrm{C}, 4000$ r.p.m. で遠沈したあと上清を静が捨てた。 てれを 2 回繰返したあと $2.0 \mathrm{ml}$ 生食水で沈渣を完全に溶解した，更に上述の merthiolate を一滴加え，全 量を一匹の家鬼両側下腿筋肉内に注射した。

以上が(1)，(2)の方法に上る初回免疫までの過程である，以下に述べるのは，抗体洒の上昇を期待して行な つた booster (追加免度) の方法であつて(1)，(2)亿共通なため，一括して述べる。初回免疫注射の日から数 えて第 4 , 第 7 及び第 9 週の初日に各々一回宛初回免疫に用いたと同じ抗原 HCG の各々 $10.0 \mathrm{mg}$ を $1.0 \mathrm{ml}$ の生食水に溶解して，家鬼耳静脈から booster 注射を行なつた。 Booster 注射直前に採取した家鬼血清を用 いて抗体価の上昇程度を測定しその成績を各 booster 注射後 3 日目に判定した。

これを一覽出来るようにしたのが Fig. 2 である，第一回目の booster 注射までに死亡した同図中に示し

Fig. 2. Antibody tioration

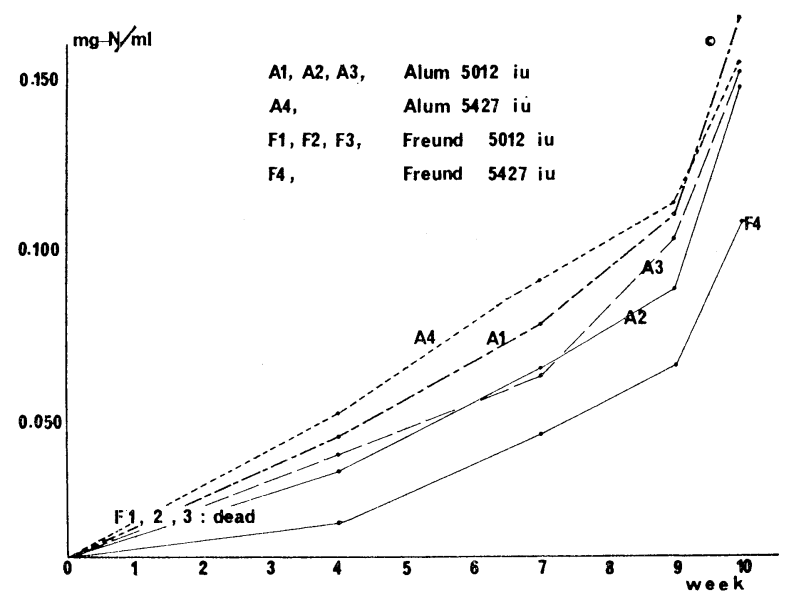

た $\mathrm{F}_{1}, \mathrm{~F}_{2}, \mathrm{~F}_{3}$ を除いて一様に抗体価の上昇を認めたが，各家鬼の抗体上昇経緯には差か認められた。初回 免疫注射後第10週目には，満足出来る抗体洒の上昇を認めたので，直ちに心臟穿刺によつて採血した。尚 F 4 は採血せず, 第 3 回目の booster 注射以後, 何らの処置も加えず生存させている.

\section{第 3 節 抗原 HCG ならびに抗 HCG 家兔抗血清の免疫学的検討}

抗血清中に存在し, 抗原と特異的に反応する抗体の力洒を示す最も合理的且信用度の高い方法として沈降 曲線法がある。従来から行なわれている, タンニン酸処理血球凝集阻止反応 (hemagglutination inhibition reaction with tannic acid treated red blood cells--HAIR と略記されている ${ }^{89990}$ ) であるとか, ラテッ クス凝集阻止反応 (latexagglutination inhibition reaction, LAIR と略記されている ${ }^{91}$ ) にみられるよう 
な，主として感度のみを採り入れた測定法よりも Heiderberger ${ }^{82}$ によつて開発された前述の窒素微量測定 法を用いて，特異的抗体量を量的に表示するこの方法がより適確さを有するものと考え，抗体の測定にはこ の方法のみを採用した (詳紐は後述).

抗原 HCG 及びその抗体検索には次の諸方法を用いた。

\section{(1) Ouchterlony 法 (寒天平板ゲル内拡散法 ${ }^{92) 93) 94)}$ )}

Ouchterlony 法は抗原と抗体を寒天平板上で拡散させ，その接点に沈降反灾を起させる，謂わば二重相拡 散法であるが，てれとは別に，単相拡散法 (single diffusion technique) が Oudin ${ }^{95}$ )によつて開発されて いる。用いた寒天は Difco 製で二重相拡散用 (double dif. tech.) として 1.0\% agar solution とした。 溶媒は $\mathrm{pH}=6.50$ に調整した生食水である。検定用抗原 HCG として 5012I.U./mgのものを用い，各々含 有蛋白量を $1.0 \mathrm{ml}$ 当り $100_{\gamma}, 200_{\gamma}, 400_{\gamma}, 600_{\gamma}, 800_{\gamma}, 1000_{\gamma}$ の抗原溶液在作り，寒天孔（well）番号 $6 \rightarrow 1$ の順に各 $0.015 \mathrm{ml}$ 注入し，中央の well には抗血清を抗原と等量注入した。 これによつて中央の well と， 1，2，3，の各 well との間に連続し且つ一本の沈降線を認めることが出来た (Photo. 1). この事実から，

Photo. 1. Ouchterlony's agar plate : 1-6 ; antigen HCG (5012 i.u./mg). $\mathrm{C}$; anti-HCG rabit antiserum.

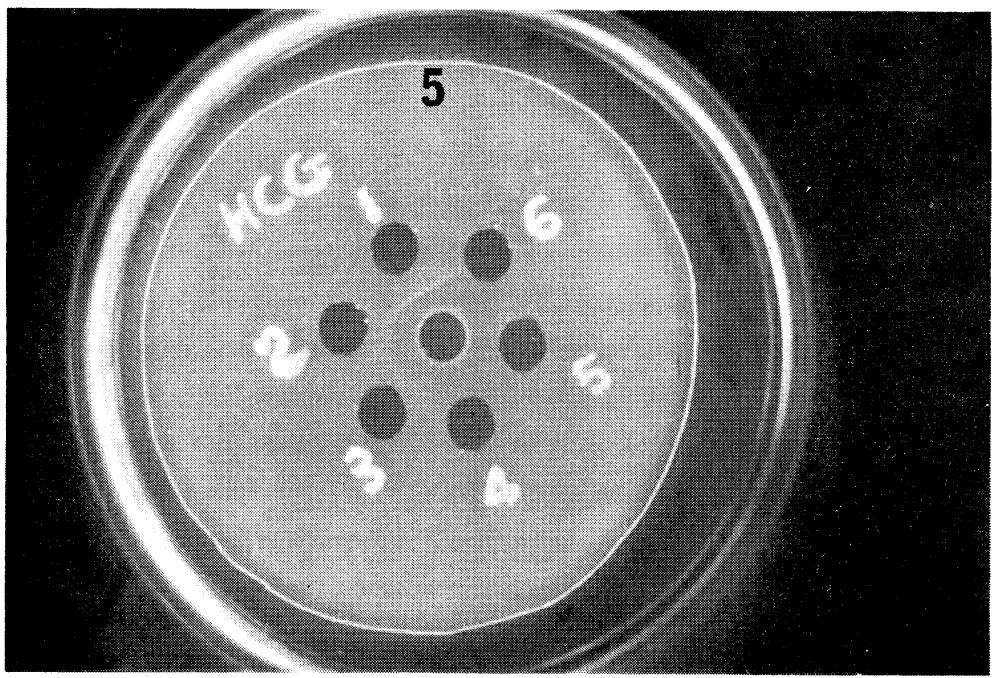

抗原 HCG と抗血清との間には特異的に反応する一つの抗原抗体反応系を涩めたが，後述する如く，免疫 電気泳動所見では，必ずしもこれと一致した成績ではなかつた。

\section{(2) 沈降曲線法 (precipitin curve in vitro) ${ }^{96) 97) 98)}$}

肝要なととは, 抗体量を正確に測定する必要上，抗体と最も強く反応する対応抗原量を上述の Ouchterlony 法で検討した結果に基づいて抗原蛋白のもつ抗原域及び抗体域の凡その值を予じめ知つておかねばならない ことである。

これによつて加えるべき抗原量の大略值を見当づけ，試験管中で捖原抗体应応を起させその complex か ら抗体に加えた抗原の蛋白量を㚇し引くことによつて抗体量を知ろうというのがての方法である. Ouchterlony 法では抗原抗体反応の感度が鈍く，特に沈降線を認めなくなる抗原及び抗体相互、の最低濃度附近に注目 する必要があるので，沈降曲線法では抗原 HCG の蛋白量として $50 \gamma, 100 \gamma, 200 \gamma, 300 \gamma, 400 \gamma, 500 \gamma$ の系

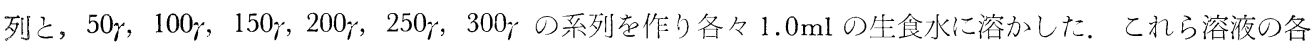
$0.10 \mathrm{ml}$ ネスラー試験管に分注し，乙の各々に0.10 $\mathrm{ml}$ 抗向清を加え，既述の merthiolate の一滴を加え 
て両者を十分混合せしめ， $37^{\circ} \mathrm{C} ， 2$ 時間正確に incubate した後 $4{ }^{\circ} \mathrm{C}$ 低温室にて 30 時間静置した。乙うし て得た抗原抗体反応による特買的 complex は極めて微量であるため，てのままの状態から直ちに上清を捨 てず，冷却 PBS, $\mathrm{pH}=7.20$ 及び生理食塩水を約 $5 \mathrm{ml}$ 加え, $4{ }^{\circ} \mathrm{C}, 2500$ r.p.m., 30分間遠沈し，管底に complex を密着させて後上清を十分に捨て去り，窒素微量測定法によつて complex の総蛋白量を求めた。更に計算 によつて抗体蛋白量を求めた。この值をグラフにしたものが Fig. 2 及び Fig. 3 であり，後者は前者の $\mathrm{A}_{1}$,

Fig. 3. Precipitin curve

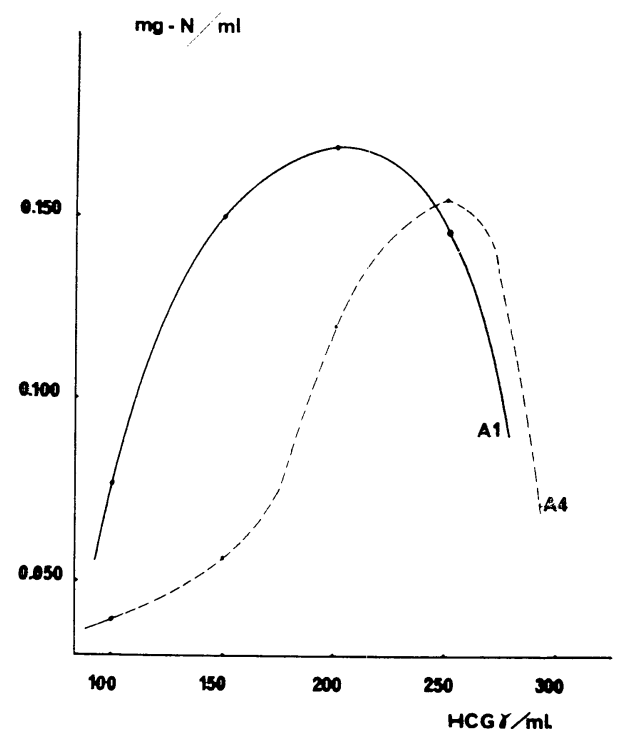

$\mathrm{A}_{4}$ を例としたものである．Fig. 2 ではこの方法で 測定した各時点での最高值を記した。

\section{（3）電気泳動法 (electrophoresis)}

電気泳動法を利用した分析方法として現在広く用 いられているものに，沪紙泳動法（paperelectrophoresis)，分画泳動法 (Zone-electrophoresis) 免疫 泳動法 (immunoelectrophoresis) などがあり，可 成の成績が得られることは事実であるが，てれらに も当然方法論的な限界があることは言をまたない。 既に多くの報告者が指摘し，又同一正常人血清につ いて photometric pattern, immunoelectrophoretic pattern の二種及び starch gel electrophoretic pattern 在それぞれ対比しつつ論評を加え, electrophoretic analysis のもつ限界を指摘した報告は枚 举にいとまがない991100)1011027103)104). 少なくとも， 限界を作り出す要因としては，i）用いた buffer の $\mathrm{pH}$ 值, ii) その $\mathrm{pH}$ 值によつて mobility の 異なる分子か泳動出来るかどうか，iii）極めて少 量に含まれて，しかも mobility が似た第 2 成分 が，活性面で重要な役割をるつ場合，果して鑑別

しうるか否か，iv）例え mobility が同じであつても必ずしも同一物質であるとはいえずその逆も亦成立す るといつた点があげられる。特洒素，ホルモン，抗体等，特異的な生物学的活性をもつ蛋白部分が，その 物質の含有総蛋白量の極く一部分である場合には，泳動法によつて得た種々の成分の中で，その裹にかくれ て主体をなす蛋白部分が同動する可能性は否定出来ない，例えば $\mathrm{pH}=6 \sim 8$ では血清 albumin は単一組

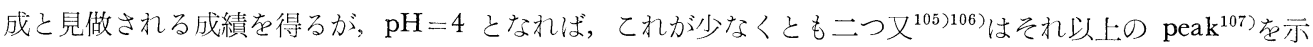
すという報告がある。乙の他にも種々の問題点が考学られるが，てのような前提にたつて抗原 [ HCG，抗 HCG 抗体及び䋐毛上皮腫患者 HCG について電気泳動分析をなつてみた。

\section{(i) 抗原 HCG}

沪紙電気泳動法に用いた装惧は Spinco Model R (Durrum 式 ${ }^{108}$ ) であり,電気装置は Beckman Duostat である。緩衝液には Veronal buffer solution, $\mathrm{pH}=8.6$, イオン強度 $0.1 \sim 0.05 \mu の も の を$ 用いた。緩衝液 の処方は Beckman の方法 ${ }^{109}$ に従つた。本実験中における buffer のイオン強度は $\mu=0.075$ であつた。

抗原 HCG の溶液濃度は 5012I.U./mg のものの $10.0 \mathrm{mg} / \mathrm{ml}$ (蛋白濃度 $6.0 \mathrm{mg} / \mathrm{ml}$ ) である。溶媒は生食 水とした。用いた沪紙は Schleicher and Schnell 社製の Beckman ¥320046である。通電条件は定電流 $2.5 \mathrm{~mA}$ ，電压 $70 \mathrm{volt} ， 16$ 時間泳動である。泳動終了後， $110^{\circ} \mathrm{C}$ 前後で急速汇沪紙を乾燥させ，約 30 分後 amidoschwartz 染色法と過沃度酸フクシン染色法を併用した。抗原 HCG のもつ蛋白部分は Fig. 7 の如人, $\alpha_{2}$ 部分に peak をもち， $\alpha_{1}$ 及び $\beta$-globulin 領域に亘る泳動像を得た。

これは Lunenfeld ${ }^{10)}$ がほぼ同様の条件下で行なつた成績とほぼ一致した。このことから，5012I.U./mgの 純度の，正常妊娠初期妊婦尿中 HCG は $\alpha_{2}$-globulin を主成分とした proteohormone であるといえそう 
Fig. 4. Antigen-HCG Paper-electrophoretic Analysis

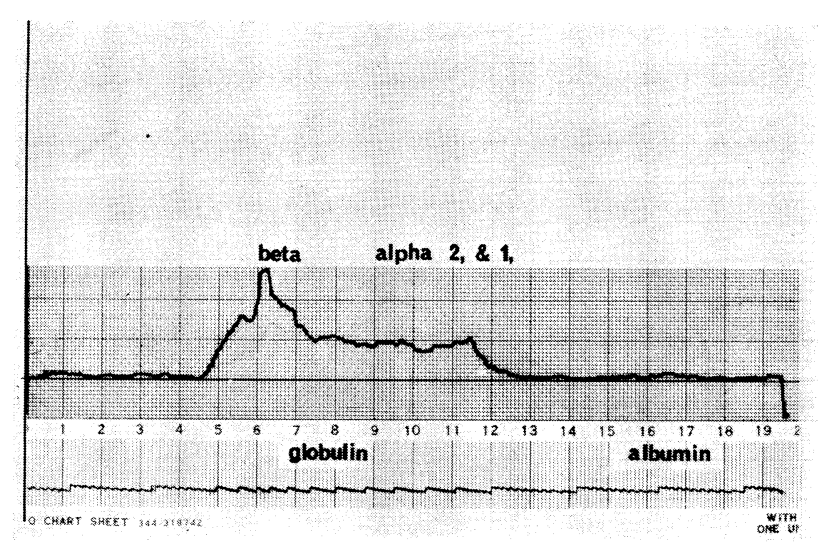

である (Fig. 4).

\section{(ii) 抗原 HCG 及び抗 HCG 抗体}

抗原 HCG 及び抗 HCG 抗体の性状をより正確に把握するためには，霆気泳動法における久点を可及的 補いつつ, 矢張り Grabar ${ }^{111)} の$ 創案した immunoelectrophoretic analysis を行なう必要がある。衆知の通 り，これは寒天ゲル内でまず電動泳動を行ない，更に Ouchterlony 法と同じ原理によつて泳動分離された各 蛋白分画と抗体又は抗原との間の沈降反応をみようというものである. 現在用いられている泳動用支持体と しては上述の agar gel のほかに cellulose acetate, cyanogum 及び starch gel がある。本実験でも，一 般に用いられる如く agar gel を用いた。この実験で用いた電気装置は菅垣社製で，Hirschfeld ${ }^{112)}$ 改良型で ある。寒天は Difco 製の repurified agar で，寒天濃度 $1.0 \%$, slide glass 上の寒天の憬さは $1 \mathrm{~mm}$ である。 寒天の溶解にはまず $2.0 \% の$ agar solution を純水溶媒で作り, 全部が加熱溶解されてから $60^{\circ} \mathrm{C}$ 前後で緩衝 液を加えて $1.0 \%$ とした。緩衝液は Laurell 処方の変法で113), discontinuous buffer system であり. Table 2 に示し通りである。泳動には 2 枚連続の slide agar plate を常用したので通電条件は，定電圧 160volt， $32 \mathrm{~mA}, 45$ 分間である。沈降曲線が適確に得られるためには，抗原過剩もしくは抗体過剩にならないことが必 要であるから寒天板上の溝又は孔の大きさも, 抗原, 抗体の濃度を変化させると同様に種々変化させてみた。

Table 2

\begin{tabular}{|c|c|c|}
\hline \multicolumn{3}{|c|}{$\begin{array}{l}\text { 1. Paper-E., } \\
\text { (Beckman buffer B-2) }\end{array}$} \\
\hline \multicolumn{2}{|c|}{ Veronal-Na } & 15.40 \\
\hline \multicolumn{2}{|c|}{ Diethyl barbituric acid } & 2.76 \\
\hline \multirow{2}{*}{\multicolumn{3}{|c|}{$\mathrm{pH}=8.6 \quad \mu=0.075$}} \\
\hline & & \\
\hline \multicolumn{3}{|l|}{ 2. Immuno-E., } \\
\hline & Bath & Agar \\
\hline Veronal & 2.76 & 3.32 \\
\hline Veronal-Na & 17.52 & 20.02 \\
\hline Ca-lactate & 0.766 & 3.072 \\
\hline Aq. dest. & 2 lit. & 2 lit. \\
\hline \multicolumn{3}{|c|}{$\mathrm{pH}=8.6 \quad \mu=0.1 \quad 0.05$} \\
\hline
\end{tabular}

Fig. app. 1.
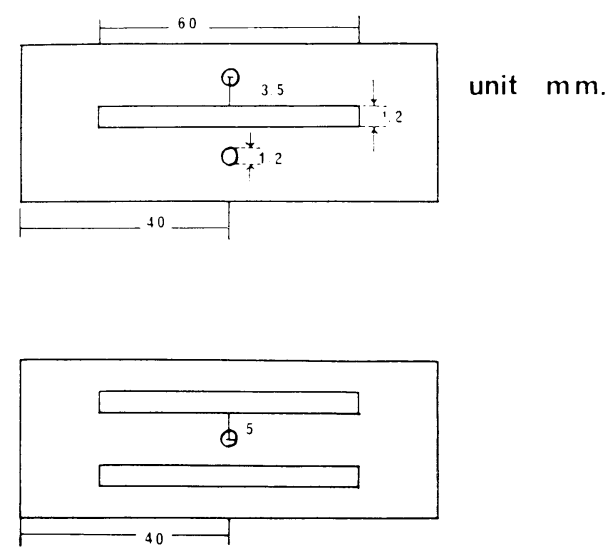
Photo. 2.

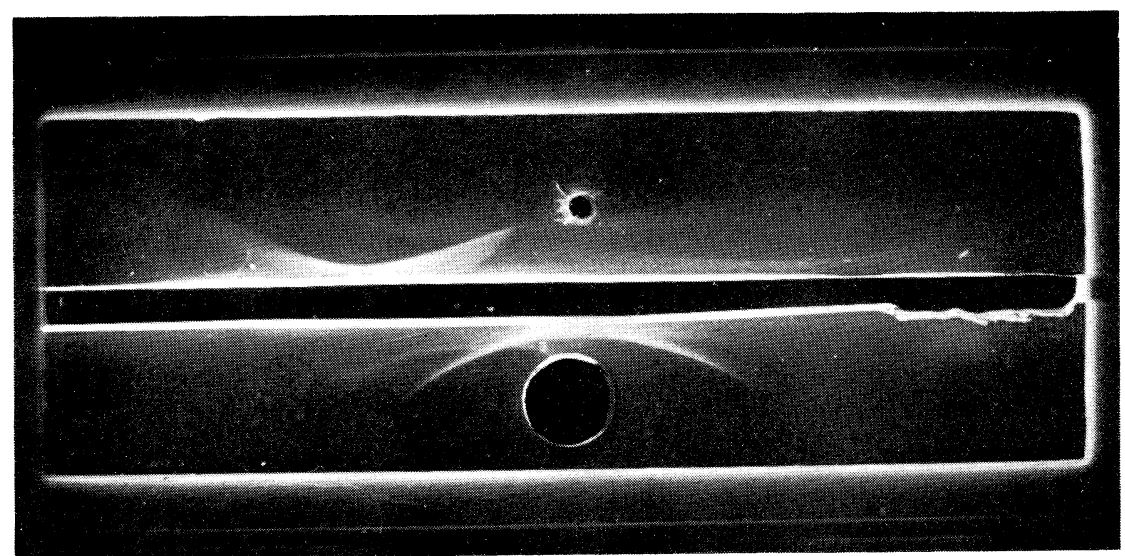

- ; Normal human serum

anti-HCG rabbit antiserum

A1. ; antigen $\mathrm{HCG}$ Gl.

Photo. 3.

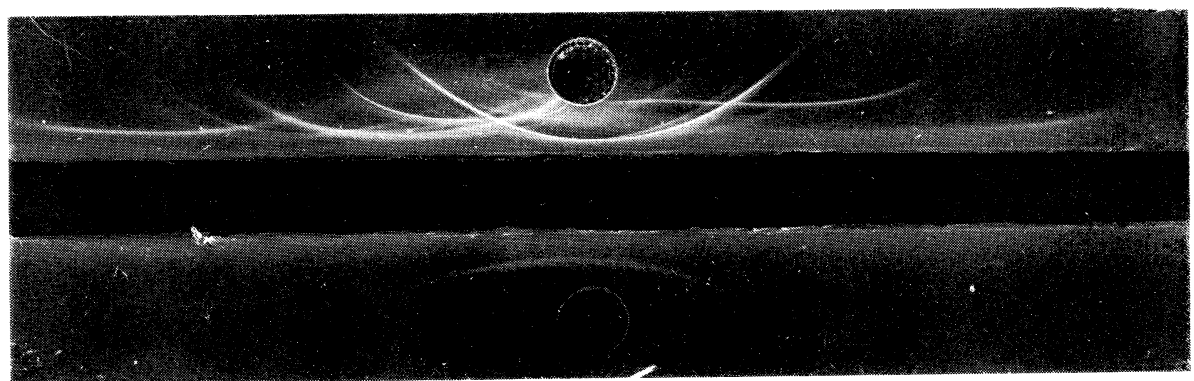

; Normal human whole serum

anti-normal human whole serum rabbit antierum

Al.__ _ _ - Gl.

; antigen HCG

原法は Fig. app. 1 に示した。 反灾停止には寒天板を $\mathrm{pH}=7.2$ の PBS に浸し，液を数回取換えたあと， 24 時間蒸留水で洗涤した. Photo. 3 は正常人全血清 (NHS 子略記) 及び抗正常人全血清家鬼抗血清 (antiNHS と略記) t中介として 5012I.U./mg の抗原 HCG $10.0 \mathrm{mg} / \mathrm{ml}$ (蛋白量 $6.02 \mathrm{mg} / \mathrm{ml}$ ) の場合の分析成 績である。前二者間には21本の沈降線が識別さ机た。抗原 HCG と anti-NHS との間には $\alpha_{2}$ から $\beta$ globulin 領域に沈降線を一本垫めたに過ぎない。このことから，抗原 HCG は沪紙電気泳動所見とほぼ同 ビ成績を得たのであつて，乙れらを総合すると，現段階では，本実験に用いた抗原 HCG は $\alpha_{2}$-globulin を主蛋白成分とするホルモン物質ということが出来る。一方抗 HCG 家逅抗血清中に含まれる HCG 抗体 の存在する分画を検索するため, 抗血清の種々の希釈液を作つてみた。即ち原濃度抗血清量を 1 とし, 希釈 生食水量との比をとつて Table 3 に示した希釉系列を作り，抗原 HCG についても原液を $10.0 \mathrm{mg}-\mathrm{HCG} / \mathrm{ml}$ とし，同じく希釈溶媒として生食水を用いた希橎系列を作つた。乙れは既に前節で述べたように，抗 HCG 家鬼抗血清中の抗体蛋白量は peak 值 $0.169 \mathrm{mg}-\mathrm{N} / \mathrm{ml}$ を示したから，てれに相当する蛋白量を含むように 
Table 4 Eluting buffers

Table 3

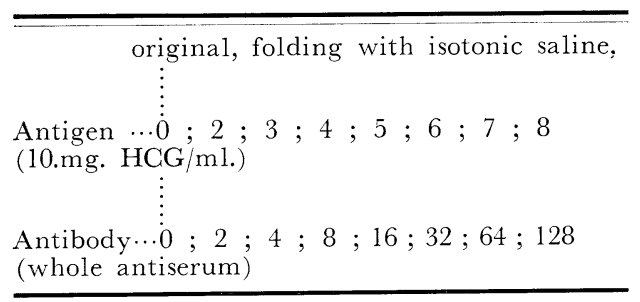

\begin{tabular}{|c|c|}
\hline \multicolumn{2}{|l|}{ Fx. $1.0 .05 \mathrm{M} . \mathrm{pH}=6.40$} \\
\hline $\mathrm{Na}_{2} \mathrm{HPO}_{4} \cdot 7 \mathrm{H}_{2} \mathrm{O}$ & 7.504 \\
\hline $\mathrm{NaH}_{2} \mathrm{PO}_{4} \cdot \mathrm{H}_{2} \mathrm{O}$ & 936 \\
\hline Aq. dest. & 2.0lit. \\
\hline Fx. II. 0.10M. $\mathrm{pH}=640$. & \\
\hline $\mathrm{Na}_{2} \mathrm{HPO}_{4} \cdot 7 \mathrm{H}_{2} \mathrm{O}$ & 15.008 \\
\hline $\mathrm{NaH}_{2} \mathrm{PO}_{4} \cdot \mathrm{H}_{2} \mathrm{O}$ & 19. \\
\hline Aq. dest. & \\
\hline
\end{tabular}

Fx. III. 1.0-N. NaCl

$\mathrm{pH}=7.0$

抗血清ならびル正常人血清の希釉液を用いて泳動及び搪散を行なつたわけである. Photo. 2 は抗 HCG 家 鬼抗血清中の抗体分画を示すものであり, NHS と抗 HCG 家鬼抗血清との間には $\gamma$-globulin 領域と共に albumin 領域にも沈降線を言忍》た。乙の albumin 領域における沈降線に対する解釉は, 抗 HCG 家鬼抗 血清中に含まれる albumin 分画の夾雑物が正常人全血清中の albumin 分画中のものと夾雑反応を惹起し たものであろうとの結論に達した，尚 albumin 領域における抗体の局在は理論的に不可能であるが，albumin と HCG の結びつきは, HCG の血中移送と関連して考学るならば必ずしも否定出来るものではなく この点については目下検討中である。

\section{第 4 節 粗グロブリン抽出}

心藏穿刺法により採血した抗 HCG 家鬼血液を, 血清分離後に $4{ }^{\circ} \mathrm{C}$ ，30分間，2500r.p.m. で遠沈した。 血清の保存は一切低温 $\left(4^{\circ} \mathrm{C}\right)$ を澉守した。飽和硫安溶液 (saturated ammonium sulfate) を用いて粗グ

Photo. 4. Outerlony's agar plate : 1-6; patient's serum of hydat. mole. C; gamma globulin extracted from anti-HCG rabbit antiserum. $(1 ; 1$, $2 ; 12,3 ; 1 / 3,4 ; 145 ; 1 / 5,6 ; 1$ $/ 10$ original concentration).

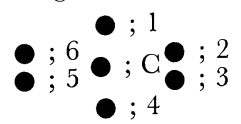

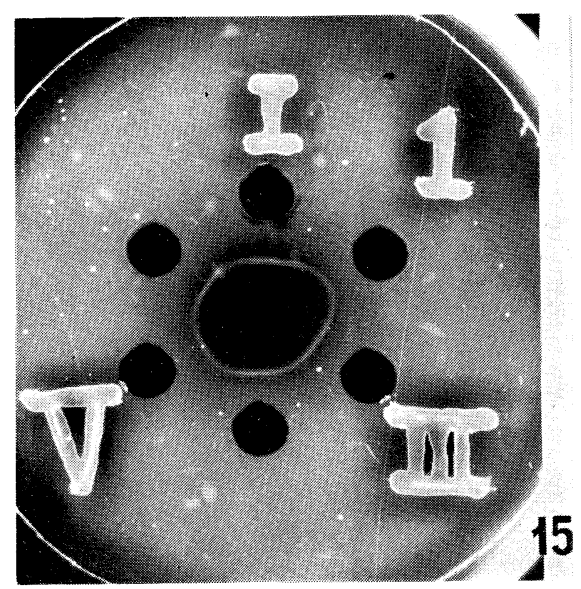

Photo. 5. Ouchterlony's agar plate ; 1-6 ; patient's serum of chorionepithelioma. C ; gamma globulin extracted from anti-HCG rabbit anti serum. $(1 ; 1,2 ; 12,3 ; 1 / 3,4 ; 14$, $5 ; 1 / 5,6 ; 1 / 10$, orig. concentration).

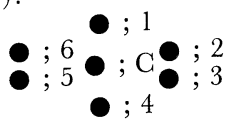

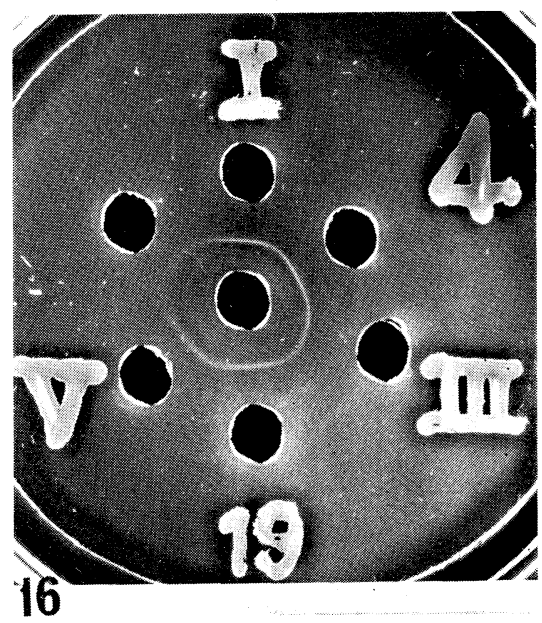


ロブリン (crude globulin, $\mathrm{Cg}$ と略記) を抽出するのに，半飽和法と1/3飽和法の二通りがあり，抗 HCG 免疫グロブリン抽出にも二通りが用いられている。半飽和法によれば Cg のみならず， albumin の抽出を 马包含する可能性が考光られ，報告例に上礼ば後者の方法によるものが多い，あらかじめ行なつた両方法で 抽出物を電気泳動したところ，共に albumin の混入を認めなかつた (Fig. 5)。したがつて半飽和法を採

Fig. 5. Grude globulin of anti-HCG rabbit antiserum

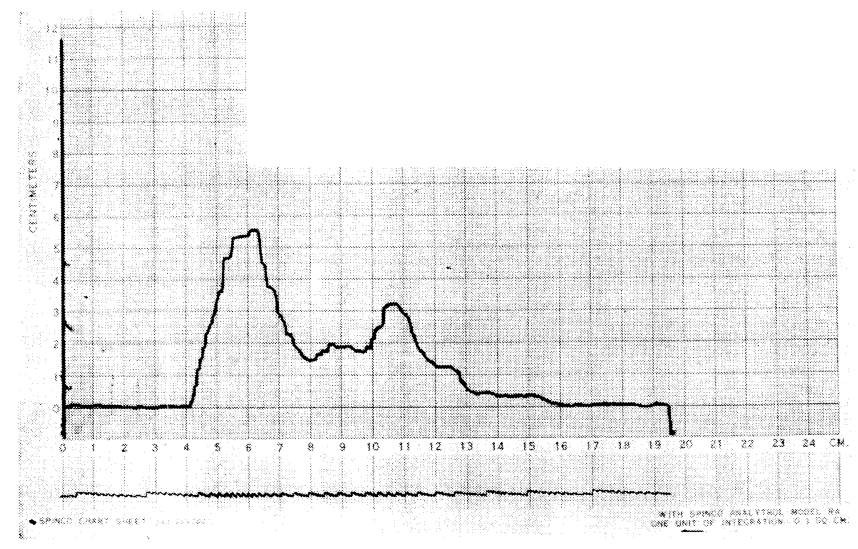

う， $\mathrm{gg}$ と考えられる蛋白分画の収量を多くならしめた。採取出来た血清量は家鬼 3 匹分で総量 $98.7 \mathrm{ml}$. で あり，1家鬼当り $22.90 \mathrm{ml}$ 。であつた．以下の記述は 1 家鬼当りの抗血清量に対して採つた方法である. $22.90 \mathrm{ml}$. 中, $0.90 \mathrm{ml}$ を諸検査のために残し， $22.0 \mathrm{ml}$. 亿対し，等量即ち $22.0 \mathrm{ml}$ 。の飽和硫安溶液を徐々

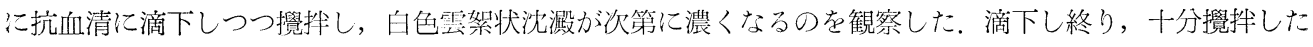
あと，乙の沈洪浮遊液をそのまま $4{ }^{\circ} \mathrm{C} ， 24$ 恃間遮光静置した。すでに報告した処では ${ }^{66)}$, 飽和硫安液を血清 量の $1 / 2$ としたが，乙扎 $1 / 4$ 飽和法に相当し，その際 albumin の混入なきととを確め更に血清量の $1 / 2$ 量 の飽和硫安液を滴下したてとを附記する。 24 時間後 $4{ }^{\circ} \mathrm{C} ， 15$ 間，4000r.p.m. で遠沈し，上清を分離した。 こ の上清を沪紙電気泳動にかけたところ，globulih 分画は根跡的でありほぼ確実に Cg は抽出され，沈渣に 移行したてとを確認した。 $4{ }^{\circ} \mathrm{C} の$ 条件で，取り出した沈渣を $11.0 \mathrm{ml}$ の生食水で十分に溶解し，乙れに等量

Fig. 6. Extracted gamma globulin of anti-HGG rabbit antiserum

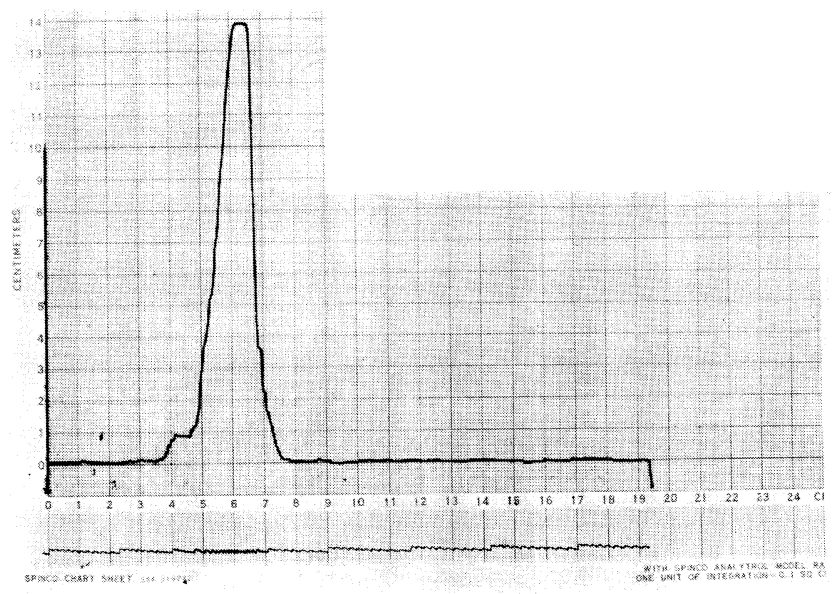


Fig. 7. Paper-electrophoretic patterns of anti-HCG rabbit antiserum

1, Whole serum

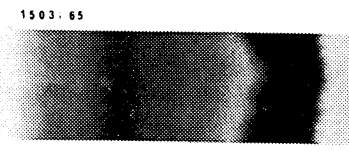

2, Crude globulin
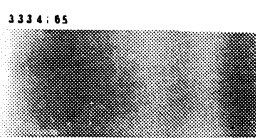

3, Gamma globulin 3335: 65

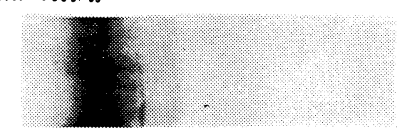

gamma glob.

albumin

の飽和硫安液を加光て沈澱を生ぜしめ，前回と同じ 条件で遠沈し上清を分離した。この際溶解する生食 水量は適当でよいが，原血清量の $1 / 2$ 量とした。 こ の操作を二回繰返し，Cgの洗涤操作を終つた。洗 滌後の沈渣は最終的に $5.0 \mathrm{ml}$ の生食水に溶解し, 透 析膜に封入し, Fig. 8 に示す方法で㹂找透析を行なつた。

透析液は $\mathrm{pH}=7.20$ の PBS を用い，頻回の透析液の交換を行ない Viulet 反応，Nestler 反応が共陰性 になるまで十分な透析を行なつた，透析開始後72時間で両反応共陰性になつたが念のため更に24時間透析を 続けた。

\section{第 5 節＼cjkstart螢光色素附加過程ならびに蛍光抗体液の採取}

螢光抗体液を作製する過程として次の二つの方法を採つたので，その概要を記述する。

\section{(1) $\mathrm{Cg}$ ·蛍光色素直接結合法}

これは $\mathrm{Cg}$ 溶液に直接螢光色素を結合 (conjugate) したあと，螢光結合免疫グロブリン分画を採取する 方法である。透析を終了した $\mathrm{Cg}$ 生食溶液中の含有蛋白量を窒素微量測定法を用いて測定したとてろ, 総量 $131.28 \mathrm{mg}$ であつた。

上述の通り $\mathrm{Gg}$ の免疫学的諸検相のため，その $0.1 \mathrm{ml}(\mathrm{Gg}=2.61 \mathrm{mg})$ を消費したので，実際に螢光色素 結合に用いた量は $128.67 \mathrm{mg}$ というととになる。総 $\mathrm{Cg}$ 量の $1.0 \%$ の制に carbonate-bicarbonate buffer solution を加え, $\mathrm{Gg}$ 生食溶液中の $\mathrm{Cg}$ 重量が 10.0\%となるよう更に生食水を添加した。螢光色素は過去 の報告例によ机ば，通常含有 $\mathrm{Cg}$ 量対色素の重量比が20：1〜 40：1の割合が適当とされているが，螢光染 色の結果の良否の一つの要因とされている色素対蛋白のモル比 ( $\mathrm{F} / \mathrm{P}$ ratio) を可及的低く且特異的染色力 価が高くなるようにしなければならない，しかし Gg の如く凡ゆる血清 globulin 蛋白を含有すると考光 られる場合には，面一的に比率を決めるのは困難である。一応従来の重量比を参考にし，且つ気温，湿度条 件を併せて色素の忣湿性を含めて不可避的実験誤差を20\%と見做し, 実質的重量比が $60 ： 1$ となるよう色素 量を $2.58 \mathrm{mg}$ とした，Cg 生食水溶液に螢光色素を加元，攪抖により conjugate したが，色素は FITCを 用いたので $4 \mathrm{C} ， 6$ 時間の攪挥で十分であつた。言うまでもなく，色素・蛋白の conjugate は一様でなけ ればならず，満足な攪找状態維持には紼心の注意を払つた。㩭找終了後は前述のPBS で透析を行ない， non-conjugated amines を徹底的に除去した。透析效果は通常 4 ～5 日間の頻繁な外液交換で十分之され ているが，この実験では外液量 $2 l の$ 容器で14回交換し，透析開始後80寺間で外液中の free amines の検出 
は陰性となつた，Gg に結合した螢光色素液から，抗 HCG 抗体蛋白に結合した分画だけを採取し非特異 因子を除去しなければならない，抗 HCG 抗体は，前述の如く 分画を採取するために DEAE-cellulose (Serva 製115)116)117)) column chromatography 法を用いた。 Cellulose の capacity 0.93, 螢光色素結合 $\mathrm{Gg}$ 液 $1.0 \mathrm{ml}$ 亿対して乾燥 cellulose を $1.0 \mathrm{~g}$ の割合にした。 こ の cellulose te $1 \mathrm{~N}-\mathrm{NaOH}$. 1N-HCl. $1 \mathrm{~N}-\mathrm{NaOH}$ 各 $500 \mathrm{ml}$ 宛, この順序で洗い, cellulose の ion-activation を行なつた。

Cellulose は $\mathrm{pH}=12$ 以上の強アルカリ性を示しているため, 蒸留水で更に洗涤し, $\mathrm{pH}=8.40$ に調整し た上で column chromatography 管に充塡した. 24 時間, $4{ }^{\circ} \mathrm{C}$ 亿静置したあと, 更めて $\mathrm{pH}$ 測定を行なつ たところ $\mathrm{pH}=9.50$ を示した．再度蒸留水で cellulose を洗涤し， $\mathrm{pH}=8.40$ になつたてとを確かめて再度 充填し24時間静置した。翌日 column chromatography 管内液が $\mathrm{pH}=8.40$ を示すことを確かめて，まず starting PBS を十分流下せしめ管内 cellulose の環境を整え更に24時間静置した。第 1 分画用 PBS を流下 せしめて以降それを採取し終るまでの経過は Fig. 9 亿示した通りである.Autofraction tube は 1 管当り 17 ml採取出来るようにした，採取管番号 18 から 22 に至る 5 本，総量 $85 \mathrm{ml}$ を 1 つにまとめ，透析膜に封入して，

Fig. 9.

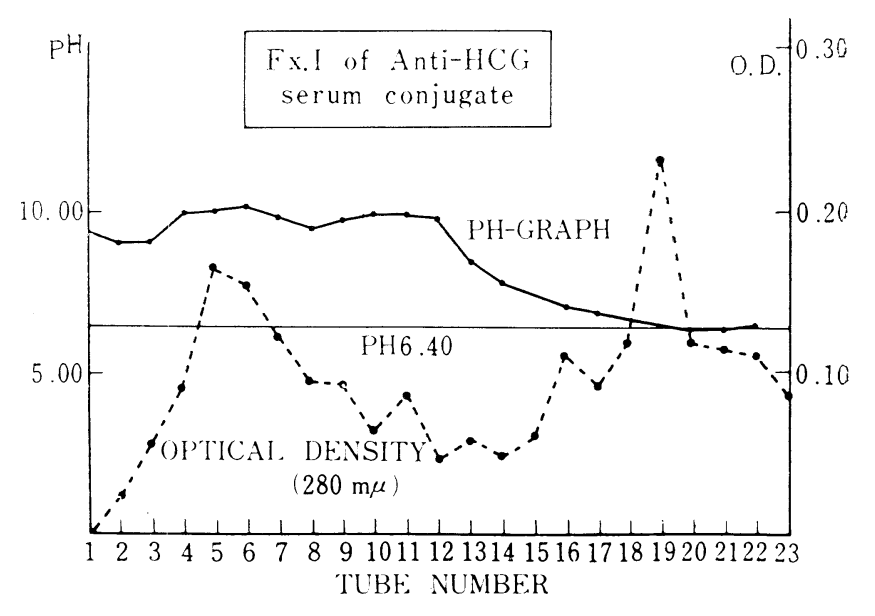

Fig. 10. Fx. II. and Fx. III. of Anti-HCG conjugate fraction O.D. $=280 \mathrm{~m} \mu$.
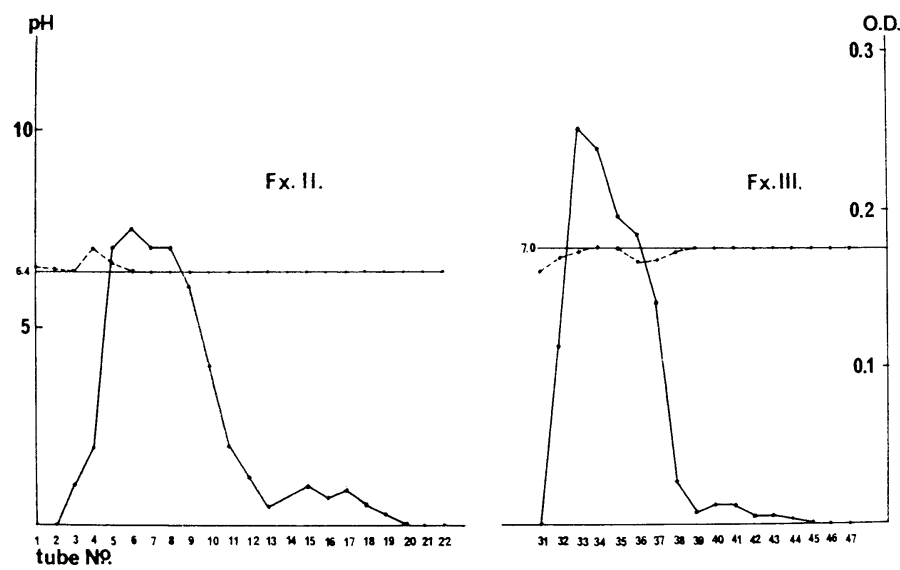

第 44 巻 第 8 号 
corbowax で濃縮し，F/P=1.3 の第 1 分画 (Fx. I) を得た. Fx. I の最終収量は $8.5 \mathrm{ml}$ であつた. てれを 更めて透析膜に封入し直し staining PBS で $4{ }^{\circ} \mathrm{C}$, 約 100 時間透析した. てのあと第 1 分画に続いて第 2 分 画用 eluting PBS, 第 3 分画用食塩水 eluting solution を順次流下せしめて第 2 分画 (Fx. II)，第 3 分画 (Fx. III.) を採取した. 経過は Fig. 10 に示した.

また各々の eluting PBS は Table 3 そ一括した.

\section{(2) $\gamma$-globulin 分画に蛍光色素を結合する方法}

この方法は，半飽和硫安法によつてまず Cg を抽出し，直ちに透析後 DEAE-cellulose を用いて $\gamma$ globulin 分画を採取してれに螢光色素を結合させる方法である.(1)に用いたのとは別の抗 HCG 家兔抗血 清総量 $20.0 \mathrm{ml}$ 用い(1)に述べた方法で Cg を抽出し, 透析したあと column chromatography で分画した. ltube 当り $15.0 \mathrm{ml}$ eluted solution が集まるようにした。操作ならびに cellulose は(1)に同じである.

Fig. app. 2 に示した経過で $\gamma$-globulin 分画を得た。図中 tube $\$ 4$ から 9 までの 6 本, 総量 $90 \mathrm{ml}$ を carbowax で濃縮し，ほぼ全体量が $5 \mathrm{ml}$ 以下になるようにした。 てれを再び透析し，終了後測定したとてろ総容

Fig. app. 2. Antiserum by DEAE-cellulose column chromatography

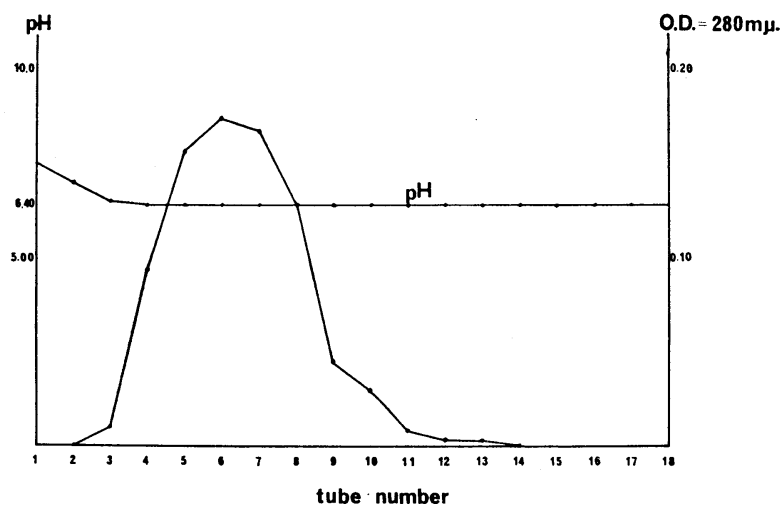

量 $3.1 \mathrm{ml}$, 総含有蛋白量 $32.5 \mathrm{mg}$ であつた。(1)の方法に従つて生食水及び carbonate-bicarbonate buffer を 加えて 10.0\%蛋白溶液とし，乙れに60：1となるように FITC を加えた．色素量は $0.67 \mathrm{mg}$ である. 十分攪 拌してから Sephadex G25118)119)120) (pharmacia fine chemicals, Sweden) を用いて column chromatographyにより非結合色素の除去を行なつた. Sephadex の量は conjugate $1 \mathrm{ml}$ に対し $4 \mathrm{~g}$ とし. Eluting buffer は 0.01M, pH=7.1, saline PBS を用いた. Eluted conjugate は(1)と同じく F/P 比を測定し，乙 れが1.3となるように濃縮した， F/P の計算式は下記の如くである.

$\mathrm{F} / \mathrm{P}=\frac{\text { 色素 } \gamma / \mathrm{ml}}{\text { 色素分子量 }} / \frac{\text { 蛋白量 } \gamma / \mathrm{ml}}{\text { 蛋白分子量 }}\left(\right.$ FITC 分子量 389.38 Rhodamin 分子量 536.08 蛋白分子量 $16 \times 10^{4}$ )

\section{第 6 節 非特異因子の除去}

1950年 Coons \& Kaplan ${ }^{57)}$ は藏器を用いて非反応性螢光色素の吸着を提唱し, 用いる臓器は当面する抗原 抗体反応系に従つて決めるべきであるといつている. 亦 Coons は1958年陽 ion 交換樹脂 (Dowex 2 chlo-

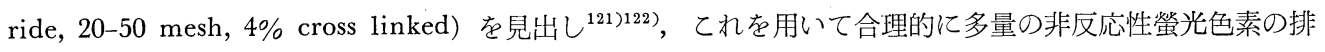
除が可能なるととを指摘した. 1961年, Consden ${ }^{123)}$ らにより non-ionic gel filtration medium (Sephadex G25）が開発され，低分子 (非反応性螢光色素) と高分子 (蛋白結合性螢光色素) を分離可能にした. し かし，2-band system による分離法のためとの Sephadex 法も尚藏器吸着57)127)125)を経れば一層その効果を 高めるものであり, 本実験過程でも次に記すような蔵器吸着を試みた。 この際最も問題になるのは, 既に諸 報告にみる, 抗 HCG 抗体が生物活性面からみた他の gonadotropins と Ouchterlony 法において沈降反応 
がみられるという点である。

現在てうした pituitary gonadotropins のみならず non-species specific gonadotropins の存在も否定し 得ない (NIH-Sheep LH or. FSH の存在と human LH との関係等 ${ }^{43744) 126) 127)}$ ) とてろであれば，それら の生体内分布，動態（人及び供用動物）が十分には明らかにならないのに，従来の臟器吸着法を無批判に採 用するのは避けなければならない，しかし諸点を考察の上，正常家鬼肝 homogenate で吸着するととが最 も可なる方法であろう．肝 homogenate を用いず，DEAE-cellulose による場合と比較しても得た所見か らは差を認めなかつた。乙れは単に DEAE-cellulose のみで非特異因子の除去が可能なととを物語るが， より念を入れて一旦 DEAE-cellulose を念た螢光抗体液を更に肝 homogenate で吸着した。 その方法を述 べる. 螢光抗体液 $1 \mathrm{ml}$ に対し正常家鬼肝 $10 \mathrm{~g}$ を用い，等量 (W. vol.) の生食水を加え，低温で waring blender を用いて homogenate とし, 更に生食水を加えて 20\% homogenate suspension 20\%を作り, 螢 光抗体液を混じて10分間，12000r.p.m. の遠沈を行ない，その上清を用いた。 かくして得た螢光抗体液は抗 HCG 特異抗体から成り立つとい光るが, 尚抗 HCG 抗体の含まれる分画住して抗人 gamma globulin 抗体 (Anti-HGG) そ，更にてれを specialize し て抗人 7S-gamma globulin 抗体 (anti-7S) 飞各 々螢光色素を附加して control とした。 その他 Control に用いた conjugates は, Table 5 亿示し た通りである。

\section{第 7節 組織切片作成法}

ての実験を通じて最も大切なととは，水溶性蛋白 hormone である HGG を如何にして組織内に留め 且つその抗原性を保存するかというととである。過 去の報告者達によれば61)62), 組織の新鮮さと抗原性 の保存のために，主として凍結切片を用いているよ うであるが，ての実験では螢光抗体法の諸研究者達 の報告を参照にして，Sainte-Marie ${ }^{128)}$ の方法による paraffin 包埋組織に主体を置いた。乙の他塗抹標本 ${ }^{129}$ 亿よる方法，凍結標本による方法 ${ }^{130) 1311132) 133 \text { )134 }}$

Table 5 Control conjugates against HCG

1. Anti-human gamma globulin

2. Anti-human 7-S gamma globulin

3. Fx. II.

4. Fx. III. $\}$ of anti-HCG

5. Absorbed Fx. 1. of anti-HCG with ; a : Normal human whole serum b : Non-pregnant urine c : Urine of children d : HCG (antigen)

6. Anti-human albumin

7. Anti-pregnant mare serum gonadotropin

Ad. 1. Antigen blocking test on tissue sections

2. Adsoxption of Fx. 1. of HCG by normal rabbit liver

3. Frozen sections

Jan., $1965 \mathrm{~K}$.

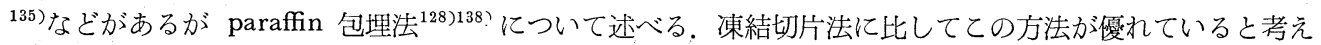
られる点は，i）切片を遙かに薄く出来ること，ii）組織保存が延長出来るととであろう. 反対に組織の収 縮が認められ，細胞，組織から特に脂質の遊出が認められるなどの点は短所といえるであろう。しかし1959 年 Carver 及び Goldman ${ }^{138)}$ ，亦1962年 Sainte-Marie ${ }^{128)}$ により十分検討され。抗原に適する固定法を選ぶこ とによつて利用価値の広いものとなり得るという結論に達したのである. 尚固定後の paraffin 切片では細 胞内抗原が顆粒状に認められることが多いといわれているが，ての原因を paraffin に求めてよいか否かわ からない. Paraffin 包埋法における注意点は paraffin 融点とその温度での抗原活性消失の問題である. HCG の活性は温度に比較的敏感なのは生物学的活性面であるが，乙の実験で行なつた包埋時間では生物活 性面の消失は最小限に防止出来ると考えられる ${ }^{41)}$. まず新鮮組織を $2 \mathrm{~mm}$ 以下の厚さとし, dry ice 亿埋め た 95.0\% ethanol に数分間浸し，その後 $4{ }^{\circ} \mathrm{C} ， 95.0 \%$ ethanol で24時間固定，次いで 99.0\%，100.0\% ethanol の順に各24時間固定した。 その翌日冷 Xylol そ30分浸し直ちに paraffin 包埋した. 切片は $3 \mu$ 以 下の厚さとし，脱 paraffin 操作はXylol を用い，脱 Xylol は上記 ethanol を濃度の高いものを順次低 くし，45\% ethanol を通してから泠 PBS で十分洗滌して染色に供した。

\section{第 8 節 染色方法}

螢光抗体法で用いられる染色方法は一般に次の 4 つである。乙の実験では(1)と(2)を用いたのでしれを詳述 
する。

(1) 直接法 (direct method 又は Coons 法 $^{139}$ )

(2) 間接法 (indirect method ; Watson 法 $^{140)}$ Coons 法 $^{141) 142)}$ )

(3) 補体法 (complement method 又は Goldwasser 法 ${ }^{147}$ )

(4) 二重染色法 (double staining method)

尚補体法では上述の Goldwasser ら又 Klein ら ${ }^{148}$ によつて始められた方法の他に Hinuma ${ }^{149}$ らの報告があ

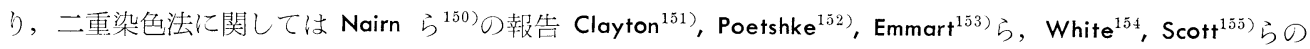
報告がある。

直接法は1942年及び1950年 Coons らによつて始められた原法で，螢光抗体液で直接資料を染色する方法 でうる。非特異染色の可能性も少なく操作も(2)に比べて簡谄である。一方間接法には Watson 原法とその後 Weller 及び Coons が mumps 及び herpes virus に用いた方法がある。前者は抗原に非螢光性特異抗体を 用いて処理した後抗 $\gamma$-globulin 螢光抗体液在滴下するものである。一方後者は切片内における抗体側の証 明に用いられた方法であり，抗体を合有する切片を0.05\%抗原液で作用させ，余剩抗原を洗滌除去させたあ 之螢光抗体で染色する方法である。一般に間接法は抗 $\boldsymbol{\gamma}$-globulin 螢光抗体液を広く利用出来る利点在もつ が，非特異染色性の範囲在拢大する可能性在もつている。

しかし Jankovic ${ }^{143}$ などはこの广法で向球免度 ${ }^{144)}$ ， Rh 团子の迫究成果 ${ }^{145)}$ を報告し， Hamashima ${ }^{146)}$ は SLEにみる抗核抗体の訨明に成果を報告している。

\section{(I) 直接法染色}

染色直前の段階にまで処理した paraffin 切片及び凍結切片の各々は, 資料部分 $1 \mathrm{~cm}^{2}$ 当り抗 HCG 螢光抗

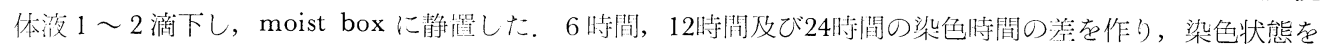
检討した. moist box は室温放嵁した。

\section{(II) 間接法染色}

これには抗正常人 $\gamma$-globulin 螢光抗体液と共に抗人 $7 \mathrm{~S} \cdot \gamma$-globulin 螢光抗体液をも併用した。抗 HCG 家鬼抗血清を資料上に滴下し，37 C，30分閒又は 1 時間 incubate したあとPBS で十分洗湺した。これに 上述二種の螢光抗体液を条々別湖に1〜2滴滴下し，直接法の要領で染色した。間接法は非特異染色の多い ことを利用して抗 HGG 染色直接法に対する control とした。

\section{第 II 章 螢光染色所見}

\section{第 1 節 人正常妊娠䄉毛組織}

\section{第 1 項 人正常妊娠初期絨毛組織}

抗 HCG 抗体第 1 分画 (既述, Fx. I), 问第 2 分画 (Fx. II), 闰第 3 分西 (Fx. III) を用いて人正常妊 娠初期縅毛組織古染色して得られた所見は次の如くである.

絨毛組織の trophoblasts 即ち䋘毛の外側を形成する $\mathrm{S}$ 細胞及びその内側で間質組縕の外側に位置する $\mathrm{C}$ 細胞及び開質組織の三者に大別して観察した，Fx. I. による特異螢光は $\mathrm{S}$ 細胞にのみ你在し， $\mathrm{C}$ 細胞，間質 組織のいずれにも存在しなかつた． S 細胞内の特異螢光像には二種の異なつた集積状態が認められた。一つ は微細顆粒状，他の一つは霉慢性に細胞内を一様に埋めるものである。微細顆粒状螢光像は $\mathrm{S}$ 細胞基底膜に 沿つて, 活ぼ直線状に配列された螢光点列, あるいは謂ゆる $\mathrm{S}$ 細胞の外側膜 (brush border) に沿う部分に 同じ螢光点列として認められ，後者は前者よりも螢光顆䊀の大きさは不規則で極論すれば大小様々であつ

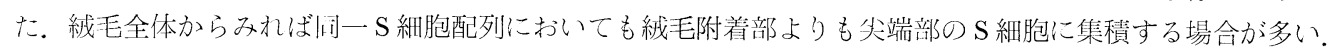

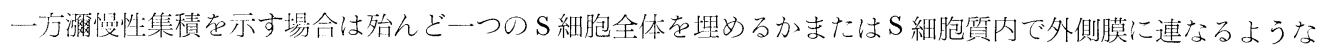
螢光集積像を呈し，基底部の螢光が涩められないのが通例であつた。Fx. II.による染色では $\mathrm{S}$ 細胞に限局

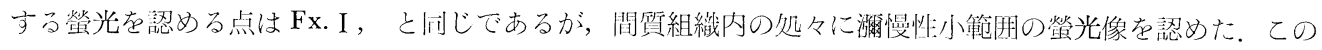

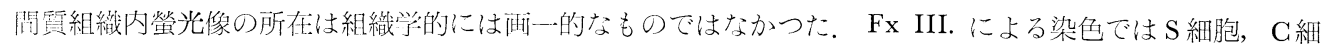

$$
\text { 第 } 44 \text { 䉥 } 8
$$


胞の区別なく一様に桷慢性に染色され，間質組織については Fx II. と同様の所見を得た。また $\mathrm{S}$ 細胞内螢 光も $\mathrm{C}$ 細胞内のそれも晸慢性あでり両細胞間の境界細胞膜は識別不可能であつた。

一方 $\mathrm{S}$ 細胞の外側膜を越えて部分的に絨毛間腔に流出したような螢光像, 即ち $\mathrm{S}$ 細胞の外側細胞膜の破壞 像を伴う如き螢光像を認めた．Fx. I. 在 NHS で吸収した螢光抗体液 (NHS-ab. Fx. I. と略す) で染色し た所見は非吸収 Fx. I. による染色所見と異なるとてろはなかつた。亦 Fx. I. 非妊正常成人尿又は小児尿 で吸収した螢光抗体液（U-ab. Fx. I. と略す）で染色しても非吸収 Fx. I. に上る染色所見と異なる点を認 めなかつた．抗人 $r$-globulin 家鬼抗血清から, 抗 HCG 螢光抗体液と同じ方法で得られた第 1 分画（既述 のAnti-HGG) で染色すると, S 細胞外側膜外 (即ち䋐毛閒腔) に沿う free human $\gamma$-globulin の染色像

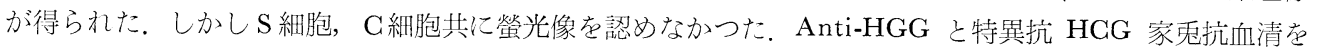
用いた間接法では Fx. I. でみられた顆粒状螢光像は認められず，澉慢性の螢光像のみであつた。したがつ て S 細胞内螢光像の詳細な分布状態は認められなかつた。抗人 $7 \mathrm{~S} \gamma$-globulin 家鬼抗血清の，同様にして 得られた第1 分画（既述の Anti-7S）で染色した場合にも得られた所見は Anti-HGG とほぼ同様のもので あり， S 細胞， C 細胞共に螢光像は認められなかつた。抗人 albumin 家鬼抗血清に Rhodamine 老標識し た第1 分画 (Anti-HAL と略記) では, 絨毛組織間質部にみられる小血管腔に極めて弱い籋慢性の螢光像 を涩めたに過ぎず， S 細胞， C 細胞共に螢光所見は認められなかつた。抗 PMS 家鬼抗血清に同じく Rhodamine を標識した第 1 分画 (Anti-PMS 々略記) では, 間質組織全体に亘る螢光像か認められ, 恰も間質 組織の構成繊維走行を示すかの如くであつた， S 細胞，G細胞共に螢光像は認められなかつた。しかし $\mathrm{G}$ 細 胞の基底膜には明らかな螢光像か渄められ，それは間質部に移行していた。一方妊娠第10週の縅毛組織で, $\mathrm{S}$ 紐胞の発芽状態と考えられる像を捉えた， S 細胞は基底膜から離脱し， G 細胞を残すだけの縅毛間質には Fx. I. による螢光像を認めず（Photo. 11），離脱した $\mathrm{S}$ 細胞には潹慢性螢光像を認めた。全体を通じて，

Fx. I. を抗原 HCG で吸収した螢光抗体液（正確には単なる螢光液に過ぎぬ）で染色しても何らの螢光像 も㢹められなかつた。組織上で antigen blocking を行なつた場合も同じであつて螢光像は認められなかつ た (Photo. 6〜9).

\section{第 2 項 人正常娃娠中期絨毛組織}

Fx. I. の染色で S 細胞に限局した濔慢性螢光像が認められた。特に形成されつつある $\mathrm{S}$ 細胞結節 (syncytial knot) にある $\mathrm{S}$ 細胞成分にほぼ集中的に螢光像が認少うれた， C 細胞成分には螢光像なく且つ細胞その もの自体の数も甚だ減少していた。一方絾毛閒腔を浮遊しているとみられる巨大な円形，無核（直径約 $30 \mu ）$

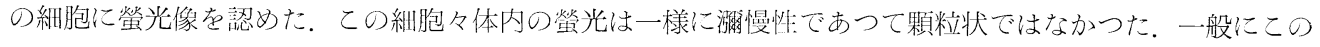
時期の䄉毛組織の示す螢光は霉慢性集積状態であり，顆粒状のものは認めなかつた．Fx. II. では $\mathrm{S}$ 細胞の

Photo. 6. Normal chorionic tissue in the 7 th week of gest. Co-existence of difiuse and granular fluorescence $(\mathrm{Fx}$. I).

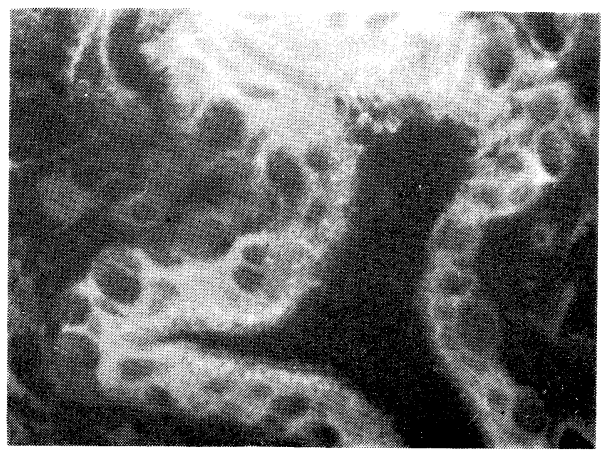

Photo. 7. Normal chorionic tissue in the 8th week of gest. difiuse type. (Fx. I).

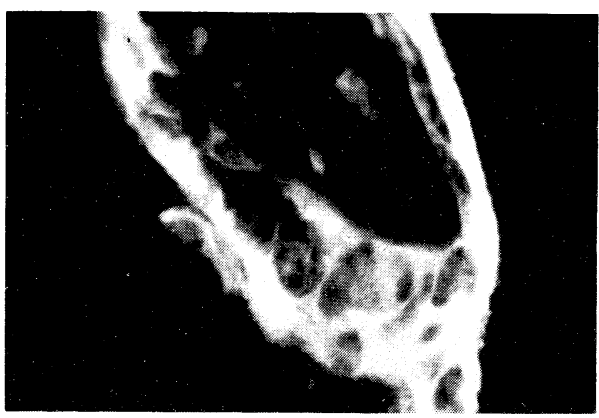


Photo. 8. Normal chorionic tissue in the 10 th week of gest. Transitional localization between fine and rough granules (FX. I).

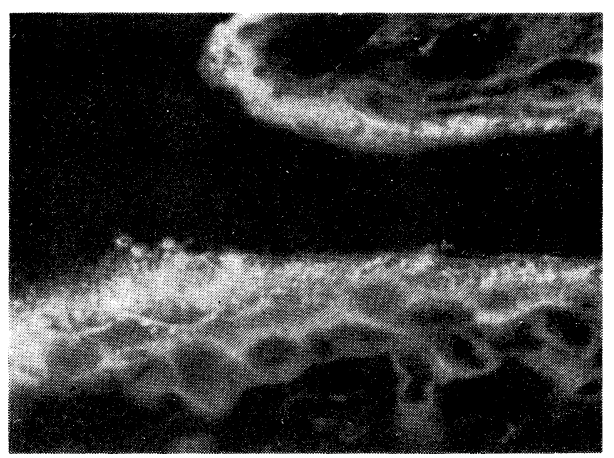

Photo. 10. Normal chorionic tissue in midtrimester. Localization in syncytial knot with free HCG-containing cells (6. M. ; Fx. I).

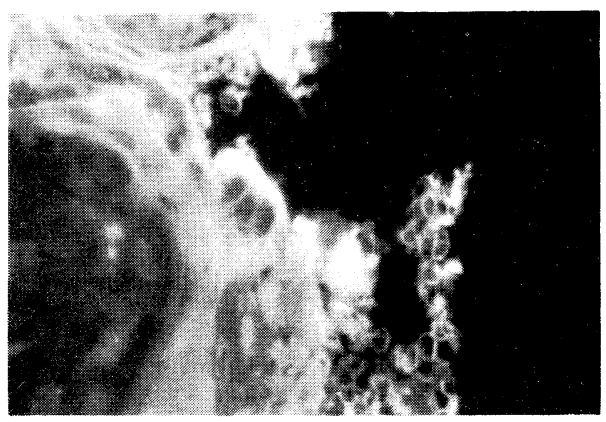

Photo. 12. Normal chorionic tissue in midtrimester. (6.M.) Localization in syncytiotrophoblasts.

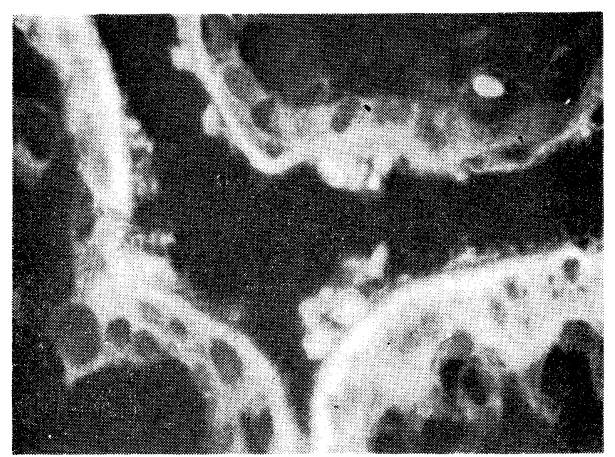

Photo. 9. Normal chorionic tissue in the 12 th week of gest. Linearly localized fine granules in syncytiotrophoblasts (Fx. I).

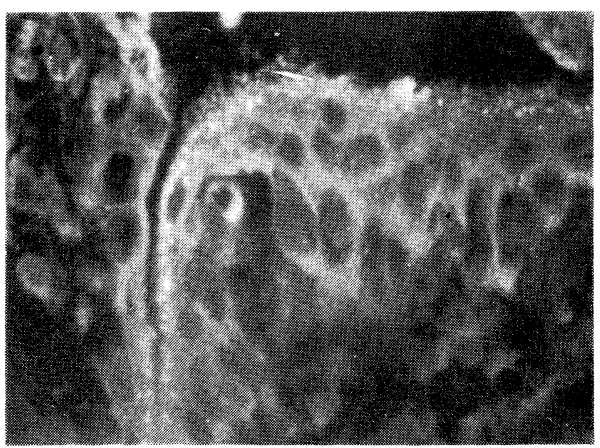

Photo. 11. Embudding trophoblasts with HCG in cytoplasms of normal chorionic tissue in midtrimester (Fx. I).

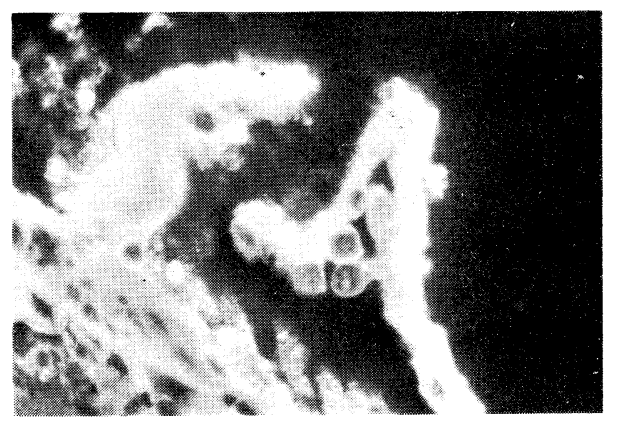

Photo. 13. Normal chorionic tissue in the 3rd trimester $(10 \mathrm{M})$. Free $\mathrm{HCG}$ containing cells can be recognized

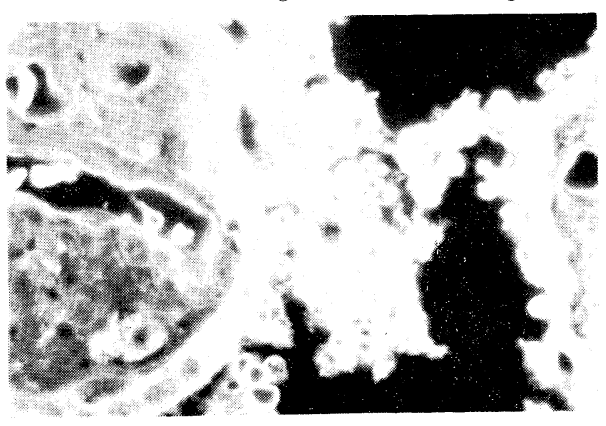




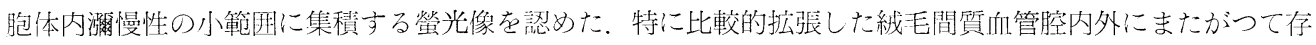
在する場合が多い，Fx. III. では，S 細胞の細胞質内，絠毛間質成分にも螢光像を認め，限定的に染別出来 る部位はなかつた，NHS-ab. Fx. I., 又 U-ab. Fx. I. の染色所見では共に Fx. I. による染色所見と同じ部 位に同様の集積状態の螢光像であつた。 Anti-HGG 及び Anti-7S では共に螢光像を認めなかつた。一方

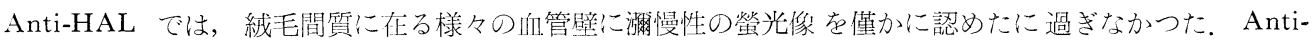

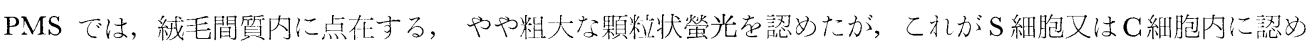
られることはなかつた。他方 Anti-HGG による間接法では Fx. I. の如く明確な S 細胞限局性の螢光像は 喼められなかつたが， $\mathrm{S}$ 細胞以外の他の䋐毛成分にも認められるものではなかつた，既述の絨毛間腔内浮遊 性の円形，無核の巨大細胞の營光像は Fx. I., Fx. II. 及び Fx. III. いずれでも滆慢性であつたが間接法で 仿一部顆粒状を呈する部分があつた.Anti-HAL, Anti-HGG, Anti-7S 及び Anti-PMS のいずれでも螢光 像は呈しなかつた (Photo. 10，12）。

\section{第 3 項 人正常妊娠末期緁毛組織}

絨毛組織は広大な間質組織と極く一部に限られた $\mathrm{S}$ 細胞結節から成立ち，且つ䦌質組織には大小様々の血

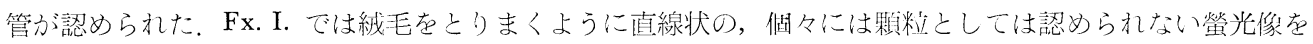
示した。 この所見は絨毛の横断切片でより一周明碓になる。

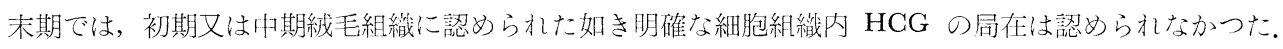
一方中期に認妨らたた巨大細胞に旅慢性螢光像か涩められたが，この時期には胞体内に必ずしも螢光をもつ 之は限らず，螢光を呈しないものもあつた，尚ての種の細胞数も中期に比して可成增加している．Fx. II. では螢光像は絨毛間質を広く埋め，特に血管周囲ならびに血管内朕にまで波及するものであつた，遊走練胞 の所見はFx. I. によるのと同様であつた。螢光像寺もつ遊走細胞数の增減もなかつた．Fx. III. では絾毛 組織，遊走細胞之共に赤血球，白向球を含めて種々の血球成分にも螢光を認めた。NHS-ab．Fx．Ｉ．及び U-ab. Fx. I. による所見は共に Fx. I. の所胃と変らなかつた。

Anti-HGG 染色では絨毛閤腔に認められる血球成分に螢光を垫めた。上述の遊走細胞には螢光を認めな かつた，Anti-HAL では特記すべき螢光像を認めなかつた。尚遊走細胞にも全く認めなかつた。Anti-7Sで

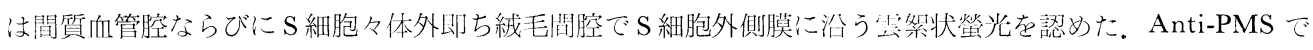

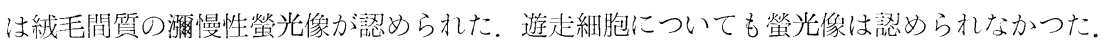

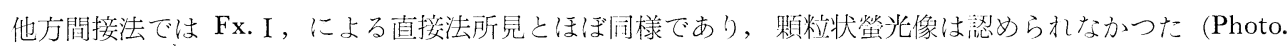
13, 14).

更に妊娠全期間を通して paraffin 切片之 frozen 切片の両者について Fx. I. 及び他の control conjugatesを用いて染色した所見では，両者間に举はなかつた。

以上，人正常妊娠絾毛組織老，ほほ采妊娠全期間に亘り通覧すると，抗 HCG 抗体に特異的に反応する組 織内 HCG は $\mathrm{S}$ 細胞に限局して存在し， C 細胞には全く螢光像として羿められないてとがわかつた。しか き上述の諸種の control conjugates では各特期の絾毛組織でほぼ共通の所見を得た。この中，初期䋐毛組 織では，S 細胞の発芽状態と考えられる所見を得，且つそれらの紐胞に螢光像を垫めた。

\section{第 2 節 胞状奇胎絨毛組織}

組織形態学的に自然排出の胞状奇胎組織は萎縮変性が強いため，まず子宮内膜搔把術により得た組織在用 い, 自然排出のもの在併用した。尚一般に trophoblasts 群の変忺:萎縮は紱毛附着部に少なく, S 細胞, $\mathrm{C}$ 細胞両成分が比較的顕著に区別出来るといわれている.

Fx. I. 染色では $\mathrm{S}$ 紐胞に限局した螢光像を涊めた． S 細胞内螢光像の分布状態には二つの翼なつた pattern があり，一つは皲慢性分布，他の一つは一見網状を呈する (netted pattern) 連続州:粗大顆粒状分布を 示すものである。乙の各々異なつた分布をもつ $\mathrm{S}$ 細胞は，相互に自ら造つた境界をもつかの如くであり，決

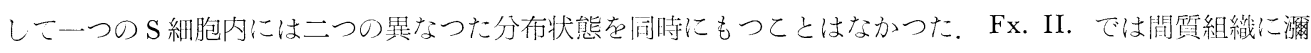

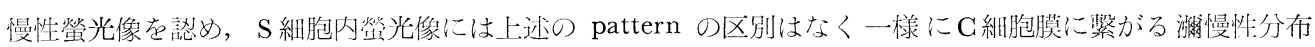


Photo. 14. Normal chorionic tissue in the 3rd trimester (8M.). Transverse section which was surrounded by HCG-containing syncytial layer (Fx. I.).

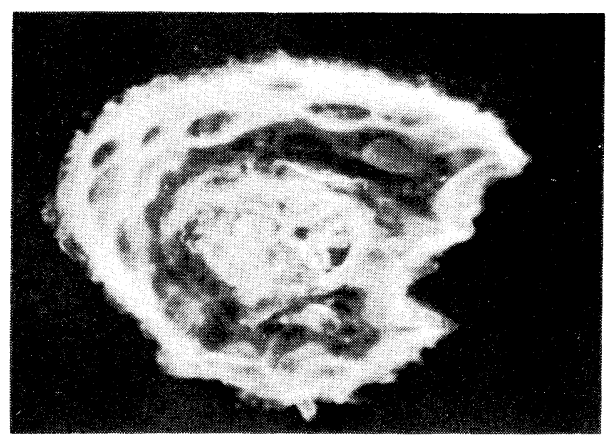

Photo. 16. Hydatidiform mole ; Co-existence of diffuse and netted type of localization (Fx. I.).

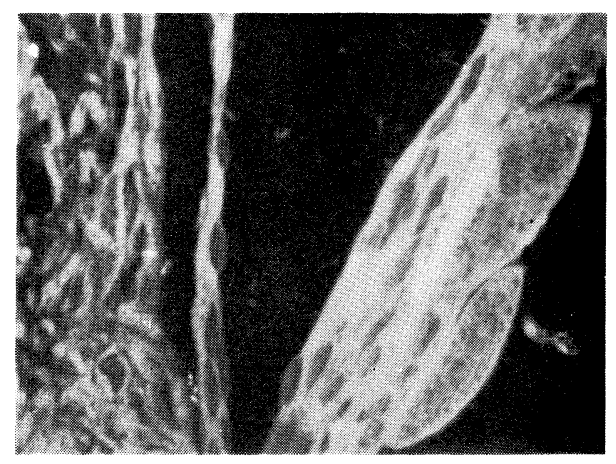

Photo. 18. Chorionepithelioma ; 'All or none accumulation of HCG in syncytiotrophoblasts (Fx.I.)

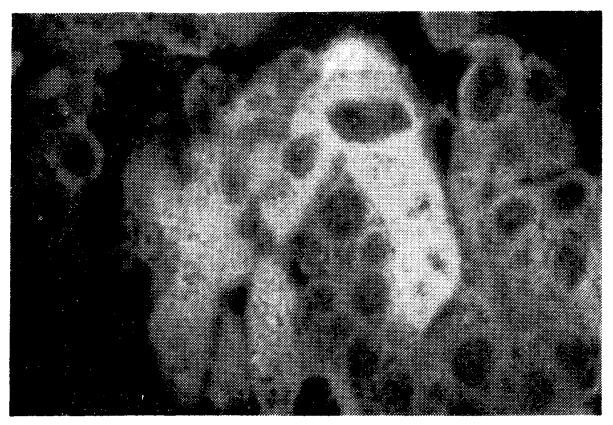

Photo. 15. Hydatidiform mole; difiuse localization in syncytiotrophoblasts (Fx. I.).

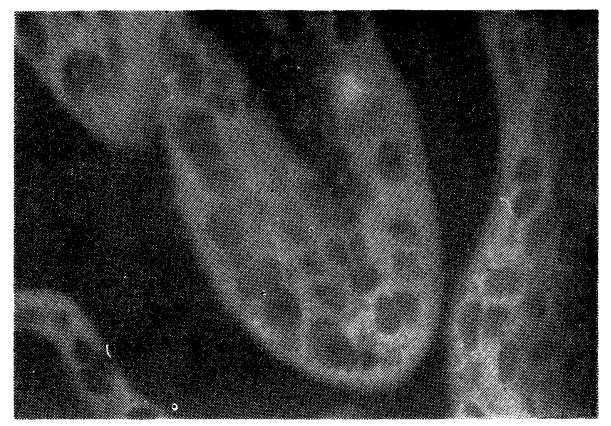

Photo. 17. Chorionepithelioma ; Netted type of localization of HCG in cytoplasms (Fx. I.).

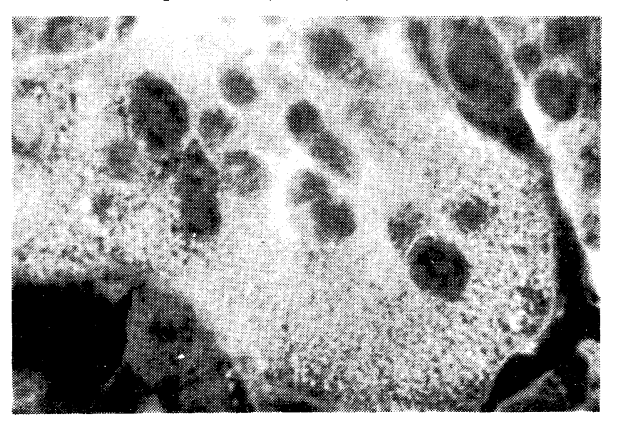

Photo. 19, Chorionepithelioma ; Granular localization in stromal region stained with Anti-PMS.

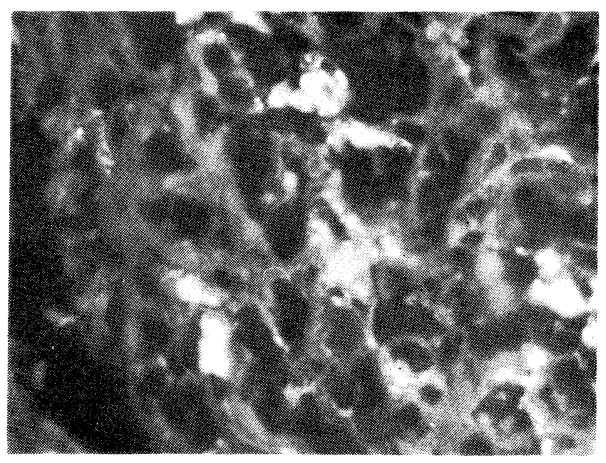


を認めた。しかし胞体内に侵入する像は認められなかつた。Fx. III. でも同様の所見であり，C細胞内に螢 光像が及ぶととはなかつた。 Anti-HGG 及び Anti-7S 共に螢光像は認められず亦 Anti-HAL によつても 螢光像は認められなかつた。間接法でも螢光像は $\mathrm{S}$ 細胞にのみ分布し, 直接法之同様に二つの異なつた分布 状態を呈した。 Anti-PMS で行なつた染色では主として間質部分に螢光を認めたが著明という程のものでは なかつた， S 細胞， C紐胞共に螢光像は認められなかつた。 NHS-ab. Fx. I. 及び U-ab. Fx. I. では共に Fx. I. で得た所見と変らなかつた. Paraffin 切片と frozen 切片での螢光分布像には殆んど差を認めなかつ たが, frozen 切片の螢光像にはやや透明度を欠くものがあつた。.これは切片の厚さによると思われる(Photo. 15, 16).

\section{第 3 節 緁毛上皮腫々瘍組織}

採取した絨毛上皮腫子宮内腫崲は明確に二つの trophoblasts 成分を含んでいた． S 細胞性及び $\mathrm{C}$ 細胞性 trophoblast 群は相互に不規則に配列され，その度合の強い点から悪性度も亦強いものと考元られる。検索 に共した部分は変性又は萎縮した組織を可及的除外して選んだ。

Fx. I. によれば，明確に $\mathrm{S}$ 細胞と $\mathrm{G}$ 細胞の染別が出来た。即ち螢光は $\mathrm{S}$ 細胞由来の trophoblast 群に限 つてその胞体内に分布し， $\mathrm{C}$ 細胞性のそれらとははつきりと境界を作つていた。しかも個々の $\mathrm{S}$ 細胞内の螢

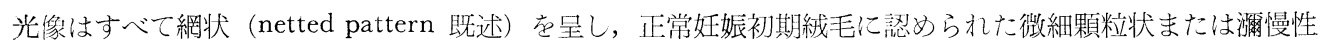
螢光像でもなかつた，その上，極めて特徴的なととは，相隣した $\mathrm{S}$ 紐胞といえども，胞体内に螢光をもつか 否かはその細胞個々の状態如何によると考元られ，胞体内に螢光を認める場合には少なくとも胞体全域を一 様の强さの螢光が網状に埋め, 特に正常妊娠初期絨毛組織 $\mathrm{S}$ 細胞に見た如き胞体内の, ある部分域に螢光像 を認めるというととはあり得なかつた。 NHS-ab. Fx. I. または U-ab. Fx. I. での染色所見は共に Fx. I. の所見と変らず，また Fx. II., Fx. III. のいずれを用いても共に S 細胞螢光像は Fx. I. と同じであつた. しかし後二者では C 細胞にも螢光を認めるようになり，しかも籋慢性であつた。

Anti-HGG 又は Anti-7S を用いても S 細胞, C 細胞及びそれらを境する細胞膜いずれの部分にも螢光像 は認められなかつた，間接法でも $\mathrm{S}$ 細胞内螢光像は網状であつて，直接法と同じであつた。また $\mathrm{C}$ 細胞内で の螢光は認められなかつた。Anti-HAL ではどてにも螢光像を認めず, Anti-PMS では間質部特に萎縮又 は変性の強いとてろに根跡的に螢光像を呈した (Photo. 17-19)。一方 paraffin 切片と frozen 切片の両者 の螢光像は大差がなかつたといえるが，後者での網状構造がやや粗雑不透师になる傾向が認められた。

以上第 II 章では，Fx. I. 及び他の control conjugates による直接法ならびに阔接法による比較所見と共 に paraffin 切片と frozen 切片による比較所見を述べたが, 既に本章第 1 節第 1 項で述べた組織内 HCG blocking test および Fx. I. 抗原 HCG で吸収した Fx. I. を用いて各々得た所見は，Fx. I. が組織内 HCG と特異的に反応する螢光抗体液であることを証明した。

\section{第III章 総括ならびに考按}

\section{第 1 節 人正常妊娠䄉毛組織}

\section{第 1 項 人正常妊娠初期䋐毛組織}

人正常妊娠第 6 週から同 15 週までの各週每の絨毛組織を検索したが，乙の侍期は trophoblast の組成とし てほぼ $\mathrm{C}$ 細胞と $\mathrm{S}$ 細胞に区分され，両者は縅毛細胞の内外二層を形作るようになり，しかも胎盤としては未 完成の時期であるため，絨毛のもつ primitive mechanism を追究するにも適した時期であるといえる ${ }^{156)}$. 一方娃娠経過中を通じて, 生物学的に検出される尿中, 血中の HCG 活性が最も豊害な時期であり且つて の実験を通じてほぼての時期に当る奸娠尿中に排泄された HCG を純化し抗原にして用いるため，抗原抗 体反応の特異性を考えるならば, 免度学的, 免疫組織学的に, 検索対象として最も基本的な侍期といえる. 既述の如く, 抗 HCG 家身抗血清から採取した，抗原に特異的に反応する螢光抗体と，組織内抗原はHCG $\mathrm{S}$ 細胞に局在し, 樰慢性（diffuse type）と顆粒状（granular type）の集積状態に二大別出来る。既に第 I 章で述べた如く，固定法その他の条件で組織内螢光の集積状態を異にするといわれており，特に ethanol 固 
定では組織の凝固収縮によつて顆粒状になるといわれているが，本実験では既述の如く操作方法並びに条件 等を統一したため, 顆粒状集積と共にそれと同時に濔慢性集積状態を認めたてとは一応細胞内 HCG の量 的問題あるいは細胞内 HGG の抗原性に差のあるととを示唆しているものであらうと考朰れる。乙れを 確認する一つの手掛りとして, 連続切片による細胞内 HCG の量的, 部位的推移を 追究せね将ならないで あろう. 単に量的, 部位的推移のみならず同時に多数の $\mathrm{S}$ 細胞内 $\mathrm{HCG}$ を, 種々の角度から眺めるととに よつて，細胞内 HCG が，細胞内でどのような動きを示すか，換言すれば，局在する細胞における HCG が, ぞのような道程を経て細胞外に出て行くかを推測するてとも可能であり, てれらを相互に関連させるて とによつて, ひいては将来の問題である HCG の性状の解明への何等かの手掛りを期待しているのである. しかし現段階においては尚々断定的結論を導くに致つてないととはいうまでもない. 初期絨毛組織内 HCG が $\mathrm{S}$ 細胞にのみ限定局在しているという螢光抗体法上の所見は, 抗 $\mathrm{HCG}$ 抗体に特異的に反応する組織内 抗原 HCG が $\mathrm{S}$ 細胞にのみ存在するてとを意味するものであるが，発生学的にみれば， $\mathrm{S}$ 細胞といえども $\mathrm{C}$ 細胞に由来するものであるからには， $\mathrm{C}$ 細胞には $\mathrm{S}$ 細胞の発生分化の過程に伴つて，HCG となるべき要 因か溉に存在しており，謂ば HCG の先駆物質（precursor）としてのある種の物質の存在を $\mathrm{G}$ 細胞中に想 定するととはあながち無謀とはいい切れない年7). 従つて HCG の precursor protein を追究すべき論拠は 十分すぎる程あるととになるが，乙の点は将来の問題とし，本題では生物学的作用をもつ.HCG そのもの を免疫学的，免疫組織学的任追究するにとどめたのである．抗原 HCG をもつて免疫された家鬼血清にお ける抗 HCG 抗体そのものが，用いる量差によつて少なくとも，in vivo 及び in vitro における HGGの もつ生物学的活性を減弱もしくは消失せしめている事実は, この抗 HGG 抗体に特異的に反応する物質て そ, 本来の目的をもつ HCG であるととを示唆しているとしてよいであろう. このととは HGG そのもの が $\mathrm{S}$ 細胞に局在していることを示す。また HCG は $\mathrm{S}$ 細胞が $\mathrm{C}$ 細胞から分化した後になつてはじめてその 産生がなされることも否定され得ない. HCG がその機能をもつようになり， S 細胞の局在から尿中に検出 される過程については，本章第 3 節にゆずるが HCG の細胞外排泄過程について得た成績から考察してみ たい，一且採取した䋐毛組織から経時的な細胞内 HCG の排泄動態を観ることは不可能である。しかし連 続切片から特定細胞内 HCG の動態と共に種々の相における細胞内 HGG の集積状態を併せ考える以外に 組織学的に選べる方法はない，ての点を前提として眺めると，細胞内螢光像の種々に異なつた集積状態を捉 え得る. 即ち(1)螢光像が極めて微細な顆粒として $\mathrm{S}$ 細胞基底膜に沿つてほぼ直線状に並ぶ像, (2)螢光像は次 第にその大きさを增し，(3)漸次細胞外側即ち絨毛間腔に向つて細胞内拡散を示す状態，(4)細胞内全体を瀮慢 性に螢光像を満たし，顆粒状として識別出来ない状態，(5)基底膜に沿う螢光像は認められず，S 細胞の外側 膜即ち謂ゆる Dempsey ${ }^{158)}$ のいう S 細胞の brush border 亿沿う部分 ${ }^{159}$ にほぼ直線状に大小不規則な顆粒 として認められる時期が別された。とれらのものを一連として考えると，HGG は S 細胞内で合成あるい は産生され, brush border を経て絨毛間腔に排出されるものといえる. 上述(1)〜(5)の順を逆に考え G 細胞 へ排出される経路は $\mathrm{G}$ 細胞における HCG の免疫活性基の分解又はその活性の消滅要团が明らかでなく且 $つ \mathrm{G}$ 細胞内螢光像を認めないととから，乙の立場は現段階では取り難い。一方電顕所見から Yoshida ${ }^{355160)}$ は 同様な排出経路を想定している (Fig. 11).

\section{第 2 項 人正常妊娠中期䋐毛組織}

ての時期に相当する絨毛組織では $\mathrm{C}$ 細胞層で消失しはじめ, ほぼ娃娠第 7 月の未項には消失し終る。事実 乙の時期の絨毛組織の横断切片では間質成分が次第に絨毛組織の広い分野を占めるようになり， $\mathrm{S}$ 細胞自身 も縮少, 融合したような形態をとり, 謂ゆる $\mathrm{S}$ 細胞結節を形成しつつあつた。螢光像はての部分にのみ存在 したことから， S 細胞における $\mathrm{HCG}$ の局在はほぼ間違いないようである。乙の時期で興味あることは， 絨毛間腔に浮遊する円形無核の大形細胞に螢光像を認めたととである. 形態学的にも機能的にも血球成分と の判別は困難な点が多いが，胞体内には一様に濔慢性に拡散した螢光像をもち，細胞の大きさは直径約20〜 $30 \mu$ と推定され，血液性遊走細胞とは考元難い．また特定の組織性遊走細胞であるかどうか疑わしい．しか し Hamazaki ${ }^{161)}$ のいう産裖子宮にみられる光輝細胞などとも異なつたものであることは，その形態並びに染 
Fig. 11. Outflow of intracytoplasmic HCG

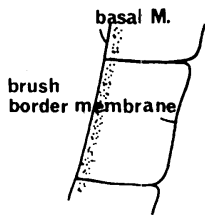

1,

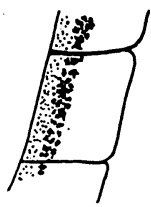

2 ,

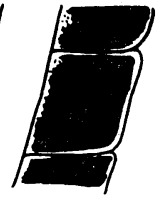

3,

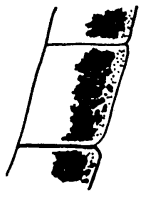

4,

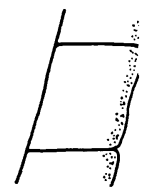

5,

process

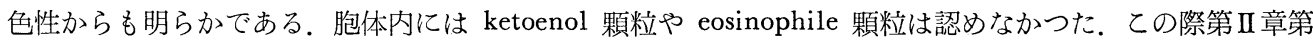
1 節で述べた $\mathrm{S}$ 細胞の発芽性が問題になるが HCG の血液中の態度を検討する上に重要であるが段階では 「緁毛間腔内遊走性 HCG 含有細胞 (free HCG-containing cell in intervillous space)」と仮称せざるを 得ない.

\section{第 3 項 人正常妊赈末期䄉毛組織}

既に紱毛組織は $\mathrm{C}$ 細胞を含壳ず $\mathrm{S}$ 細胞結節と共に広大な部位を占める間質組織の中に拡張された血管小腔 を認めるのみである． $\mathrm{S}$ 細胞と雖ども, 絨毛全体からみれば殆んど根跡的なものである．てのような絨毛組 織では，螢光像の存在部位も極めて根跡的なものに過ぎないが，少なくとも絨毛をとりまくようにして結節 部に存在するととは確認出来た。しかも螢光像は間質部への波及は認められていない. この時期で最も著明 なととは，前述の如く絨毛間腔に遊走する「HGG 含有細胞」の著しい増加である，遊走細胞内 HCG は 濔慢性螢光像として認められ，且つ細胞周辺部により著しく螢光像が集積する所見を得た. てれらの細胞も 前述の如く円形無核であつて, 第 2 項で述べたと同じ種類に属する細胞であろうと考えられる. 第 2 項で述 べた遊走細胞も亦との時期のそれらも，乙の実験でとりあげた種々の control conjugates により明らかに された如く, HCG に特異的に螢光像を示すわけであるが，何故てれらの遊走細胞が胞体内を埋めるように を含有し，乙の細胞がどういら運命をたどるかは，尚末解決なるも甚だ興味ある点と考える.

\section{第 2 節 胞状奇胎絨毛組織}

病理組織学的に胞状奇胎の成因については明らかでないが，Schiller ${ }^{162)}$ などによれば胎児の第 3 週前後の 死亡によつて, 絨毛血管の形成が行なわれず, 胎児死亡に続いて通常の流産が起るのをさまたげる程に強力 な trophoblast 群の活動力が本病発の発生原因と考えられているようであり，諸説があるがいずれにしても 妊娠初期に見られる多量の HCG 検出と trophoblast 群の異常增殖との間に密接な関連があるだろうこと は当然考えられるとてろである。しかし排出材料について，かかる点について追求するてとはほとんど不可 能であるといつてよい，しかし䋐毛附着部では, 殆んど $\mathrm{S}$ 細胞のみからなる著しい trophoblast の増殖が認 められる．乙の際てれら増殖性 $\mathrm{S}$ 細胞々体内に空胞変性も強まつている．HCG の局在を調べるためには， いずれの trophoblast 群一つに片寄つた部位のみの検討では無意味であり可及的広い局在部位にわたつて慎 重に検索した. 即ち $\mathrm{S}$ 細胞 $\mathrm{C}$ 細胞共にほぼ平等に存在し且つ変性細胞のない部位を選んだのである. 結果と して螢光像は著明に $\mathrm{S}$ 細胞由来の細胞に局在し $\mathrm{C}$ 細胞性のものには認められなかつた.

このことは，既述の HCG を抗原とした抗 HCG 抗体に特異的に反応する抗原物質が胞状奇胎 $\mathrm{S}$ 細胞に も存在するととが明らかになり，一方 $\mathrm{C}$ 細胞には上述の抗体に特異的に反応する物質は存在しないとみてよ い. 勿論既述の抗原 HCG の他に胞状奇胎に特有の HCG なる概念を導入すれば， C 細胞に関してまた異 なつた所見あるいは結果の惹起される可能性もあろうが，今後の問題としてての場では触れないでおく，S 細胞内 HCG の分布は既述の如く正常妊娠例に比して異なつたものであつた。即ち 胞状奇胎では霂慢性か 
または連続性粗大顆粒状（しかし顆粒として明らかな像ではない）で，しかも正常妊娠例の如く両者間の関 連性は全く認められなかつた。乙れは胞状奇胎排出組織の萎縮又は変性には無関係であると同時にいずれの 型の分布を示すかは $\mathrm{S}$ 細胞個々によつて異なり，同一細胞内に両者が同居した像は認めなかつた。乙れが何 を意味するか明らかでないが，連続性粗大顆粒（あるいは網状）分布は後述の絨毛上皮腫々瘍組織の場合に 一層明らかになり，乙れと規を一にする分布である，既に諸報告にみる如く胞状奇胎の患者尿中 HCG 又 は血中 HCG の biological assay 值は正常妊娠時の peak 值に比してはるが高值を示すが，螢光像ある いは免疫学的に判断する限り, 乙れを裏付ける証拠は何も得られておらず, したがつて biological な面と immunological な面との分離というととが考えられる。一方如様な分布を示す限り，どのような経過道程 を経て細胞内 HCG の排出がなされるのか不明である.

\section{第 3 節 絨毛上皮腫々瘍組織}

組織学的に特徵的なととは, 絨毛構造 (Villous pattern) の欠如と共に trophoblast 群は $\mathrm{S}$ 細胞性と $\mathrm{C}$ 細胞性のものが不規則な複合配列を示し特に G 細胞性 trophoblast が胞状奇胎にみられる以上に明らかに判 別されることである，近年悪性腫煬に hormone 様物質が認められるという執告があり，特に肺癌と hormone 様物質との関係については比較的報告例が多い，例えば肺癌と steroidhormone の関係については $\mathrm{Krant}^{163)}$ らが, 腫愓原性 ACTH と下垂体 ACTH の生物学的活性についての Liddle ${ }^{164)}$ らの報告, Cushing 症候群にみられる ACTH と肺癌についての Nichols ${ }^{165)}$ らの報告にみられる corticotropin-like substance の存在, 更には Marmorston ${ }^{166)}$ らによる腺癌と患者尿中 estrogen 等の関係についての報告があるが,

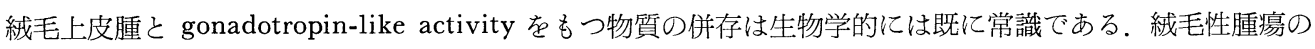
悪性か良性かの論議は別として ${ }^{167)}$, 本症では腫瘍が hormone 様物質を産生し且つ免疫学的, 免疫組織学 的にそれが検出可能である興味ある疾病であることに異論はない。しかし近年本患者尿中 gonadotropin と 妊娠性 gonadotropin との間の生物学的測定値と免疫学的測定値との間に差を認め, 両者間に性状の差を想 定する報告が散見されるようになつた。しかも䄉毛上皮腫について，Delf ${ }^{168)}$ ら以降，性状の差を無視して 生物学的測定值によつて疾病の予後を判定している傾向か強いか臨床的にてれが明らかな誤璆を生じ, 実情 に合わない例も多々あるため, 生物学的測定值のみに頼る態度そのものが見直されつつあることも事実であ る. 他方免疫学の長足の進歩に伴い単に免疫学のみならず免疫化学的な検討によつて生物学的な腫瘍性 gonadotropin の登場といつたてとか判別される時も近いというととは決して否定されるべきでないように 思われる. 以上の観点から, 免疫組織学的にみた絨毛上皮腫々瘍組織内 HCG を追究せんと試みたのであ る. この際組織内 HCG の細胞外排出機構を検討して絨腫における転移性の問題解決への足掛りともした いのである. 正常妊娠初期妊婦尿中 HCG と絨毛上皮腫にみる HCG とを同一視することには既述の如く 尚重要な問題を含み，事実絨腫性 gonadotropinの一面しか見てないという久点は否定しようもなくまた 正常妊娠性 HCG を用いて䋐腫組織内 HCG の検出を試みたという幾多の障碍となるべき事項の存在も承 知である。資料切片では $\mathrm{S}$ 細胞性と $\mathrm{G}$ 細胞性 trophoblast が複雑に入り，しかも個々の細胞は明確に相燐す る細胞と境界を作り，乙れらのうち $\mathrm{S}$ 細胞䎲のみ特異的に反応する抗原 $\mathrm{HGG}$ を含有し，細胞内螢光像の 集積は胞状奇胎像の一部としてみられた如く連続性粗大顆粒状ではあつたが全体として網状構造が一層著明 であつた。しかし胞状奇胎における他部の像である濔慢性あるいは純顆粒状の螢光集積像は全く認められず, しかも特徴的なととは, 細胞内における螢光像には量的に增減する姿, 即ち正常娃娠初期縅毛にみられた顆 粒状から漺慢性へ，更には再び顆粒状に移る姿は全く認められず， $\mathrm{S}$ 細胞内螢光像は個々の $\mathrm{S}$ 細胞をみた場 合, 含まれるか (all) 否か, (none), 換言すれば「all or none accumulation」というととに踏み切るこ とが出来る (Fig. 12). したがつて細胞内集積からみる限り, 正常妊娠初期性 HCG と䋐毛上皮腫性 HCG には性状に差があると考える方が妥当のようである。即ち, 網状集積を来す原因が, 縅毛上皮腫 $\mathrm{S}$ 細胞に存 在する空胞変性などと何等かの関連があるとは考えたくないないのであり,もつぱら抗 HCG 抗体に反応 する細胞内における HCG の存在が問題である限り, その抗体に反応する HGG の形が正常妊娠のそれと は異なると考えたいのである. 
Fig. 12. All or none accumulation in S-cell

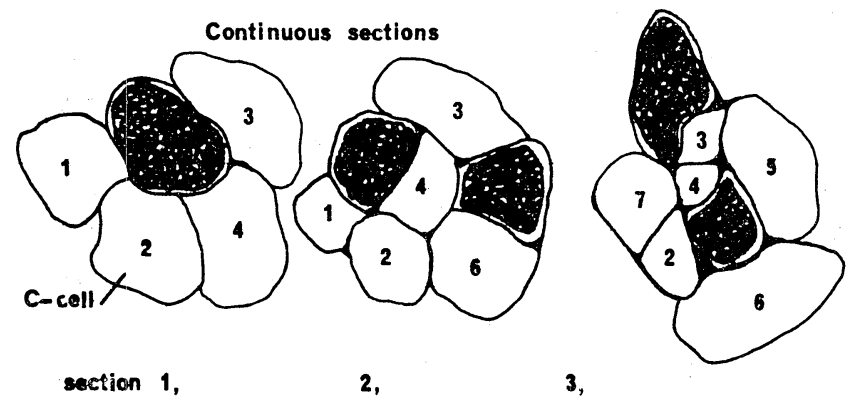

上述の如く，乙の点の解明にはさし当り先ずは絨毛上皮腫の gonadotropin を抗原として正常絨毛組織内 HCG（または gonadotropin 反応性物質）の検索を慎重に行なう必要があろう.

結 論

以上の実験成績から次の如き結論を得た。

（1）正常妊娠初期妊婦尿中 HCG の構成蛋白成分は主として $\alpha_{2}$-globulin から成り， $\alpha_{1}$ および $\beta$-globulin をも一部構成々分としたものであり，乙れは波紙電気泳動法，免疫電気泳動法による分析でもほぼ同 様の成績であつた.

(2) 正常妊娠初期妊婦尿中 HCG を抗原として得た抗 HCG 抗体は抗原 HCG と特異的に反応するも のであり，正常妊娠絨毛組織のみならず胞状奇胎䋘毛組織，䋐毛上皮腫々瘍組織における組織内 HCG の 検索に幸にして成功した.

（3）上記抗原 HCG を用いて家兔を免疫する際に，従来の関連実験諸報告にみられる Freund's adjuvant を用いると共に, 初めて alum precipitate method を用いるととによつて, 微量の抗原 HCG 量に対して 甚だ有効なる免疫促進効果のあることを知つた.

(4) 上記抗 HCG 抗体に特異的に反応する䋐毛組織内 HCG は正常妊娠絨毛ならびに胞状奇胎絿毛いず れの場合にも $\mathrm{S}$ 細胞に限局して存在し他の組織学的部位には認められなかつた。このととは䋘毛上皮腫々瘍 組織の場合でもあてはまつた。

（5）正常妊娠初期絾毛組織における $\mathrm{S}$ 細胞内 HCG の集積状態には二つの異なつた pattern があり，一 つは微細顆粒状，他は濔慢性であり両者は種々の移行型をもつていた.

（6） 中期以降の正常縅毛における HCG の集積は源慢性のものだけであつた.

（7）胞状奇胎にみられる組織内 HCG は源慢性のものと共に網状集積の二通りがあり，個々の $\mathrm{S}$ 細胞は いずれか一方の集積状態をとり，両者の混在形は認められなかつた。

（8）絨毛上皮腫々瘍細胞内 HCG の集積はすべて網状であり， S 細胞個々については all or none accumulation であつた.

（9）正常妊娠初期絨毛組織内 HCG の分泌機転については， S 細胞基底膜から同外側膜に向つて移動す るような形で外側膜（謂ぬる brush border membrane）を経ての絨毛間腔へ排出であるような模様である ことが窺われた。

(10) 胞状奇胎組織と絨毛上皮腫々瘍組織内 HCG の分泌機転については，それらの集積状態からみても 正常絨毛のそれとは異なつているだろうことが示唆されるだけで，現段階ではそれ以上のととを認識ずると とは出来なかつた.

(11) 正常妊娠絾毛組織で，胞体内に HCG を含有する S 細胞の絨毛からの発来状態を捉えにが，それら の運命については不明である。 
(12) 正常娃娠䋐毛組織の検索において中期以降の絨毛間腔に浮遊性巨大細胞の出現が認められ，乙れらに HCG が含まれることのある場合があることを捉えたが，細胞形態学的にみて，相当するものがなく，free HCG-containing cells と仮りに命名した。

(13) 性腺刺㦸ホルモンの一つであり，今回，HCG の対照の一つとして用いた抗 PMS 抗体を用いて人絨 毛組織における組織内 PMS の局在を検索したとてろ, 主として間質部に存在し絠毛上皮組織には存在しな かつた，乙れは絨毛上皮腫々瘍組織で著明であつた。

(14) HCG と PMS との間には免疫学的交叉性は認められなかつた.

擱筆するにあたり，終始御鞭撻，御指導，御校閲を頂いた恩師，西村敏雄教授に深甚の謝意を表します。 実験に際し終始御指導を頂いた京都大学医学部病理学教室浜島義博助教授に深謝します，HCG の提供を頂 いた帝国荍器株式会社に感謝の意を表します。

本論文の要旨は第39回日本内分泌学会総会において, また一部は第 3 回アジア太平洋内分泌学会において 発表した。

本論文は京都大学審查学位論文である.

\section{参 考 文 献}

1）広瀬豊一：日婦会誌，61；1055，(1920)。

2) ASCHHEIM, S. and ZONDEK, B. : Klin. Wschr., $6: 1322$, (1927)

3) PHILIPP, E. : Zbl. Gynäk., 54 : 450, 1858 \& 2754, (1930) GEY, G.O. et al. : Science, $88: 306$, (1938)

5) JONES, G.E.S. et al. : Bull. Johnes Hopkins Hosp., $72: 26,(1943)$ 6) EVANS, H.M. and LONG, J.A. : Anat. Res., $23: 19$, (1922) 7) FEVOLD, H.L. and LEONALD, D.L. : Amer. J. Physiol., 97 : 291, (1931)

8) EVANS, H.M. et al. : Endocr., 28 : 933, (1941)

9) SEALEY, J.L. and SONDERN, C.W. : Endocr., $27: 813,(1940)$ 10) BISHOFF, F. : Endocr., $30: 667,(1942)$

11) DICZFAlUSY, E. and LORAINE, J.A. : J. Clin. Endocr. \& Metab., $15: 424$, (1956)

12) ZONDEK, B. et al. : J. Amer. Med. Assoc., 128 : 939, (1945)

13) ALBERT, A. and BERKSON, J. : J. Clin. Endocr., $11: 895$, (1951) 14) SMITH, G.V. and SMITH, O.W. : Amer. J. Physiol., $107: 128$, (1938) 15) HAMBURGER, C. and PEDERSEN-BJERGAAD, K. : Quart. J. Pharm., 10 : 662, (1937) 16) DICZFAlUSY, E. : Acta Endocr., 12 : Suppl. XII, (1953) FRIEDMAN, M.H. and LAPHAM, M.E. : Amer. J. Obst. \& Gynec., 21 : 405, (1931) GALLI-MAININI, C. : Endocr. $43:$ 349, (1948)

19) MOHANTY, J.K. and PABRAI, P.R. : J. Pharm. and Pharmacol., $3: 17$, (1951) 20) WOHLYOZEN, F.X. : Arch. Expl. Path. \& Pharm., $207: 482$, (1953) 21) WATTS, R.M. and ADAIR, F.L. : Amer. J. Obst. \& Gynec., $46: 183,(1943)$ 22) LORAINE, J.A. : J. Endocr., $6: 319$, (1950) 23) DICZFALUSY, E. : Acta Endocr., $17: 58,(1954) \quad 24)$ APOSTOLOKIS, M. and VOIGT, K.D. : Acta Endocr., $28: 54,(1958) \quad 25)$ DICZFAluSY, E. et al. : Acta Endocr., $5: 226,(1950) \quad 26)$ DELFS, E. : Endocr., $28: 196$, (1941) $\quad$ 27) HEARD, R.D.H. and WINTON, S.S. : J. Physiol., $96: 248$, (1939) 28) BICKENBACH, W. : Arch. Gynäk., $17: 152$, (1941) 29) WISLOCKI, G.B. : Amer. J. Anat., 73 : 335, (1943)

30) PEARSE, A.G.E. : Nature, $162: 651$, (1948) 31) PALIK and JAJOS, L. : Gynaec., $133: 37$, (1952) 161, (1953) 33）山田英智：日内泌誌，41；593，(1965) 32) ZILLIAGUS, H. : Gynaec. 135 : Obst. \& Gynec., $88: 618,(1964) \quad 35)$ YOSHIDA, Y : Exp. cell Res, $34: 293$, (1964) COLLIP, J.B. and ANDERSON, E.M. : Lancet, $229: 76$, (1936) 37) GOSS, D.A. and LEWIS, J. : Endocr., 74 : 83, (1964) 38) ELY, C.A. and TALLBERG, T. : Endocr., $74: 314$, (1964) 
39) WILDE, C.E. : J. Endocr., $32: 117$, (1965)

40) PAUL, W.E. and ROSS, G.T. : Endocr., $75: 352$, (1964)

41）西村敏雄, 他：産婦人科の世界，17；161 \& 255, (1965)

42) WARD,

D.N. et al. : Biochem. Biophys. Acta, $50: 224$, (1961)

43) MOUDGAL, N.R. and LI, C.H. : Arch. Biochem. Biophys., 95 : 93, (1961) $\quad$ 44) SEGAL, S.J. et al. : Gen. Comp. Endocr. Suppl., $1: 12$, (1962) 45) WIDE, L. and GEMZELL, G.A. : Acta Endocr., $35: 261$, (1960)

BRODY, S. and CARLSTROEM, G. : Lancet, 9 : 99, (1960)

47) McKEAN, G.M. : Amer. J. Obst. \& Gynec., $80:$ 596, (1960) 48) FRIEDMAN, M.H. : Amer. J. Physiol., $90: 653$, (1929) 49) MAININI, C. : J. Clin. Endocr., $7: 653$, (1947)

50) 東条伸平，笠井寛司，余語郁夫：木之 臨, $14 ; 813$, (1966) 51) REINER, L. : Science, $72: 483$, (1930) 52) HEIDERBERGER, M. et al. : J. exp. Med., $58: 137$, (1933) 53) HOPKINS, S.J. and WORMALL, A. : J. Biochem., $27: 740$, (1933) 54) HOPKINS, S.J. and WORMALL, A. : J. Biochem., $28: 228$, (1934) 55) MARRAGK, J. : Natere, $133: 292$, (1934) 56 56) COONS, A.H. et al.: Proc. Soc. exp. Biol. Med., $47:$ 200, (1941) 57) COONS, A.H. and KAPLAN, M.H. : J. exp. Med., $91: 1,(1950) \quad$ 58) MARSHALL, J.M. Jr. : J. exp. Med., $94: 21$, (1951)

GRUIGKSHANK, B. and GURRIE, A.R. : Immunology, Oxf., $1: 13$, (1958) 60) MIDGLEY, A.R. and PIERGE, G.B. : Fed. Proc., $21: 198$, (1962) 61) MIDGLEY, A.R. Jr. and PIERCE, G.B. : J. exp. Med., $115: 289$, (1962) 62) THIEDE, H.A. et al. : Obst. \& Gynec., $22: 310$, （1963） 63）宮河昭夫, 他：日産婦誌，16；750，（1964） 64）野獄幸雄, 他：臨婦産誌, 19； 7, (1965). 65）中山徹也, 他：日内泌誌, 40 ; 特別号, 139，（1965） 66）西村敏雄, 他： 産婦人科治療，12；326，（1966） 67）浜島義博, 京極方久著：免疫組織学，p.133。 68) SCHULTZE, H. and SGHWICK, G. : Behringwerke Mitteilungen, $35: 37$, (1958) 69) KABAT, E.A. : J. Immunol., $47: 513$, (1943) 70) COHN, M. : Methods in Medical Research, $5: 268,(1952)$ 71) CLEASSON, L. et al. : Acta Endocr., $1: 1$, (1948)

72) MORRIS, G.J.O.R. : Brit. Med. Bull., 11 : 101, (1955) 73) KATZMAN, P.A. and DOSY, E.A. : J. Biol. Ghem., $106:$ 125, (1934) 74) PEARSE, A.G.E. : Histochemistry-Theoretical and Applied, 2nd Ed., $137 \&$ \&22, (1959) 75) NAIRN. R.G. et al. : Brit. J. exp. Path., $41: 214$, (1960) 76) RIGGS, J.L. et al. : Amer. J. Clin. Path., $34: 1081$, (1958) 77) HIRAMOTO, R. et al. : Proc. Soc. exp. Biol. Med., $97: 611$, (1958) 78) BOUCHARD : J. Chim. Physique., $33: 127$, (1936) 79）八木国夫, 吉田善一, 太幡利一 : 蛍光, 南光堂, (1936) 80) FRANK and WAWILLON : Z. Physik., 69 : 100, (1931) 81) KOGH, F.G. and McMEEKIN, T.L. : J. Amer. Ghem. Soc., 46 : 2066, (1924) 82) HEIDELBERGER, M. and KENDALL, F.E. : J. exp. Med., $50: 809$, (1929) 83) PETERS, J.P. and Van SLYKE, D.D. : Quantitative Clinical Chemistry, Vol. II, (1932) 84) BULL, H.B. : J. Amer. Chem. Soc., $66: 1499$, (1944) 85) KIRK, P.L. : Advances in Protein Chemistry, $3: 139$, (1947) $\quad$ 86) BOYD, W.G. : Fundamentals of Immunology, III Ed., (1956)

87) FREUND, J. and McDERMOTT, K. : Proc. Soc. exp. Biol. (N.Y.) 49 : 548, (1942)

88) PROOM, H. : J. Path. Bact., 55 : 419, (1943) WIDE, L. : Acta. Endocr. Suppl. 70 : (1962) 90) WIDE, L. et al. : Acta Endocr., $37: 445$, (1961) 91) ROBBINS, S.L. et al. : Proc. Soc. exp. Biol. Med., $109: 321$, (1962) 92) OUCHTERLONY, O. : Acta Path. Microbiol., $26: 507$, (1945) 93) OUCHTERLONY, O. : Arkiv. Kem. Min. Geol., B. $26: 1$, (1949) 94) OUCHTERLONY, O. : Acta Path. Microbiol. Scand., $32: 231$, (1953) 95) OUDIN, J. : Ann. Inst. Pasteur, 75 : 30, (1948) 96) BOYDEN, S.V. : J. exp. Med., 93 : 107, (1951)

97) BORDUAS, A.G. and GRABAR, P. : Ann. Inst. Pasteur, 84 : 903, (1953)

98) STAVITSKY, A.B. : J. Immunol., 72 : 360, (1954) 第44巻 第 8 号 
99) BIER, M. (Ed.) : Electrophoresis, Acad. Press, N.Y., (1959)

100) MOULD, D.L. and

SYNGE, R.L.M. : Analyst., 77 : 964, (1952)

and Paperelectrophoresis, II Ed., (1958)

Acad. Press, N.Y. Methods of Biochemic

GOOPER, D.R. : Nature, $181: 713$, (1958)

Nature, $182: 530$, (1958) 105) LUETSGHER, J.A. Jr. : J. Amer. Chem. Soc., $61: 2888$, (1939) 106) SHARP, D.G. et al. : J. Biol. Chem., $144: 139$, (1942)

107) SAIFER, A. and GOREY,

108) DURRUM, E.L. : J. Amer. Ghem. Soc., 73 : 4875,

(1951) 109) LONGSWORTH, L.G. : Chem. Rev., $30: 323$, (1942) 110) LUNENFELD, B.B. et al. : J. Glin. Endocr. \& Met., $21: 478$, (1961) 111) GRABAR, P. and BURTIN, P. : Immunoelectrophoretic Analysis, Elservier, (1955)

112) HIRSGHFELD, J. : Science Tools, $8: 17,(1962)$

113) LAURELL, C.B. et al. : Clin. Chem., $2: 99$, (1956)

114) WIEME,

R.J. : J. Immunol., $84: 93$, (1959) 115) GOLDSTEIN, G. et al. : J. Exp. Med., $114: 89$, (1961) 116) HUDSON, B.W. : Bull. W.H.O., $24: 291$, (1961) 117) PETERS, J.H. et al. : Fed. Proc., $20: 17$, (1961) 118) PORATH, J. and FLODIN, P. : Nature (London), 183 : 1657, (1959) 119) ZWAAN, J. and VANDAM, A.F. : Acta Histochemica, $11: 306$, (1961) 120) WAGNeR, M. : Zbl. Bakt., $185: 124$, (1962) 121) COONS, A.H. : Public Health Rep., $73:$ 884, (1958) 122) COONS, A.H. : In General Cytological Methods, I, 399, Acad. Press, N.Y. 123) CONSDEN, R. et al. : In Immunological Methods. Scientific Pub., Oxford, (1961) 124) COONS, A.H. et al. : J. exp. Med., $102: 49$, (1955)

125) HIRAMOTO, R. et al. : Cancer Res., $18: 686$, (1958) 126) MOUDGAL, N.R. and LI, C.H. : Nature, $191: 192$, (1961) 127) WAKABAYASHI, K. and TAMAOKI, B. : Endocr., $77: 264$, (1965)

128) SAINTEMARIE, G. : J. Histochem. Gytochem., $10: 250$, (1962) 129) GHERRY, W.B. et al. : Bull. W.H.O., $25: 159$, (1961) 130) THORNBURG, W. : J. Histochem., $4: 403$, (1956) 131) MERYMAN, H.T. : Science, $124: 515$, (1956)

132) THORNBURG, W. and MEYERS, P.E. : J. Histochem. Gytochem., $5: 47$, (1957) 133) LOUIS. G.J. : Stain Technol., $32: 279$, (1957) 134) BURKHOLDER, P.M. et al. : Stain Technol., $36: 89$, (1961) 135) TOBIE, J.E. et al. : Exp. Parasit., $11: 50,(1961) \quad$ 136) LINDERSTROEM-LANG, K. and MOGENSEN, K.R. : G.R. Lab. Carlsberg Ser. Chim., $23: 27$, (1938) 137) GOONS, A.H. : Fed. Proc., $10: 558$, (1951) 138) CARver, R.K. and GOLdMAN, M. : Amer. J. Glin. Path., 32 : 159, (1959) 139) COONS, A.H. et al. : J. Immunol., $45: 159$, (1942) exp. Biol. Med., $79: 222$, (1952) J. exp. Med., $96: 653$, (1952) Annals of the N.Y. Academy of Science, $59: 951$, (1955) 140) WATSON, B.K. : Proc. Soc. 141) COONS, A.H. et al. : 142) LEDUC, E.H. et al. : J. exp. Med., $102: 61$, (1955) 143) JANKOVIC, B.D. : Acta Haemat., 22 : 278, (1959)

145) JVNKOVIC JANKOVIC, B.D. and ARSENIJEVIC, K. : Acta Haemat., 22 : 387, (1959) B.D. and LINCOLN, T.L. : Dxperientra, $15: 61$, (1959) $\quad 146)$ 浜島義博: 最新医学, $20 ； 1123$,
$\begin{array}{lll}\text { (1965). } & \text { 147) GOLDWASSER, R.A. and SHEPARD. C.G. : J. Immunol., } 80: 122,(1958)\end{array}$ 148) KLEIN, P. and BURKHOLDER, P. : Schweiz. Z. Path. Bakt., 22 : 729, (1959) HINUMA, Y. and HUMMELER, K. : J. Immunol., $87:$ 367, (1961) 150) NAIRN, R.C. et al. : Fluorescent Protein Tracing, E \& S Livingstone, (1962) 151) GLAYTON, R.M. : Exp. Cell Res. Suppl., $7: 275$, (1959) 152) POETSHKE, G. et al. : Schweitz. Z. Path. Bakt., 22 : 758, (1959)

153) EMMART, E.W. and TURNER, W.A. : J. Histochem. Cytochem., $8: 273$, (1960) 154) WHITE, C.E. et al. : Analyt. Chem., $32: 438$, (1960) 155) SCOTT, 
D.G. : Ann. Rheum. Dis., 18 : 207, (1959)

156) 渡辺行正, 村上正名: 最新医学, $13 ; 3234$,

(1958). 157）沢崎千秋：日産婦誌, $19 ； 259$, (1967). 158) DEMPSEY, E.W. et al. : Amer. J. Anat., $96: 65$, (1955) 159) BOYD, J.D. and HUGHES, A.F.W. : J. Anat., $88: 356$, (1954) 160) YOSHIDA, Y.: Exp. Cell Res., $34: 311$, (1964) 161) HAMAZAKI, Y. : Virchows Arch., Bd. 295, (1935) 162) SCHILIER, W. : Amer. J. Cancer, $35: 2$, (1939) 163) KRANT, M.J. : Arch. Intern. Med., $115:$ 464, (1965) 164) LIDDLE, G.W. et al. : Arch. Intern. Med., $111: 471$, (1963)

165) NIGHELS, J. and GOURLEY, W. : J.A.M.A. Aug., 31, 696, (1965) 166) MARMORSTON, J. et al. : Amer. Rev. Resp. Dis., $92: 404$, (1965) 167) NOVAK, E.R. : Gynec. \& Obst. Pathology, p. 677, (1962) 168) DELFS, E. : Obst. Gynec. 9 : 1, (1957) 